\title{
IX Konferencja Naukowo-Szkoleniowa Sekcji Audiologicznej i Sekcji Foniatrycznej Polskiego Towarzystwa Otorynolaryngologów - Chirurgów Głowy i Szyi, 16-17 maja 2014 r., Katowice
}

SALA A

\section{6 maja 2014 r., piątek}

\section{Sesja II • Audiologia}

\section{Wykorzystanie różnych systemów implantów słuchowych zakotwiczonych w kości (BAHA) w leczeniu chorych $\mathrm{z}$ niedosłuchem}

Marek Zadrożniak, Marcin Szymański, Janusz Klatka

Klinika Otolaryngologii i Onkologii Laryngologicznej, Uniwersytet Medyczny, Lublin

Słowa kluczowe: implant słuchowy zakotwiczony w kości (BAHA) • niedosłuch • głuchota

Implanty słuchowe zakotwiczone w kości (BAHA) z powodzeniem stosowane są do leczenia niedosłuchów w wielu ośrodkach w Polsce. Na przełomie ostatnich lat w tej metodzie leczenia wprowadzono wiele innowacji: implanty o większej szerokości, różne długości wsporników, nowe powłoki wsporników, systemy oceniające stabilność implantów w kości, magnetyczne systemy implantów bez wspornika penetrującego przez skórę. W prezentowanej pracy przedstawiamy wyniki implantacji BAHA w niedosłuchach przewodzeniowych, mieszanych i jednostronnej głuchocie z wykorzystaniem systemów BAHA dostarczanych przez różnych producentów u pacjentów operowanych w Klinice Otolaryngologii i Onkologii Laryngologicznej Uniwersytetu Medycznego w Lublinie w latach 2009-2013. W tym czasie 24 pacjentom wszczepiono implant o szerokości 3,75 mm i długości 3 lub $4 \mathrm{~mm}$ (Cochlear, Oticon), 9 pacjentom implant o szerokości $4 \mathrm{~mm}$ i długości $4 \mathrm{~mm}$ (Oticon), 2 pacjentom implant magnetyczny bez wspornika penetrującego przez skórę (Sophono, Baha Attract). Operacje wykonywano techniką cięcia liniowego lub z użyciem dermatomu, w znieczuleniu ogólnym lub miejscowym, $\mathrm{z}$ wykorzystaniem wsporników o różnej długości. W prezentowanej pracy przedstawiamy wiek pacjentów, płeć, wskazania audiologiczne, techniki operacyjne, powikłania pooperacyjne, odstęp czasu od operacji do momentu podłączenia procesora mowy, korzyści słuchowe oceniane za pomocą audiometrii słownej w wolnym polu słuchowym.

Percepcja słuchowa mowy pacjentów postlingwalnie ogłuchłych implantowanych po 60 roku życia

Joanna Rostkowska, Anna Geremek-Samsonowicz, Joanna Kobosko, Henryk Skarżyński

Światowe Centrum Stuchu, Instytut Fizjologii i Patologii Stuchu, Warszawa/Kajetany

Słowa kluczowe: percepcja słuchowa • CI

Wprowadzenie: Głęboki niedosłuch poważnie ogranicza czynności poznawcze i jest obciążający dla funkcjonowania osób w każdym wieku, także w wieku późnej dorosłości. Utrudnia podejmowanie wyzwań, zmniejsza aktywność społeczną, obniża jakość życia, przyczyniając się do przyspieszenia procesu starzenia. Celem pracy jest ocena poziomu percepcji słuchowej mowy pacjentów postlingwalnie ogłuchłych, zaimplantowanych po 60 roku życia.

Materiał i metody: W badaniach uczestniczyło 40 pacjentów podzielonych na dwie grupy według kryterium wieku wszczepienia implantu ślimakowego. Do pomiaru możliwości słuchowych, po co najmniej roku korzystania z urządzenia, zastosowano 5 podtestów baterii testów MED-EL oraz próbę „Język chiński”.

Wyniki: Wszyscy badani pacjenci niezależnie od wieku w momencie implantowania osiągnęli wysokie wyniki w zakresie percepcji słuchowej głosek, wyrazów i zdań ze zbioru otwartego.

Wnioski: Zastosowanie implantu ślimakowego umożliwia seniorom osiąganie takiego poziomu percepcji słuchowej, jaki jest dostępny pacjentom młodszym. Wiek nie powinien być najistotniejszym kryterium w procesie 
diagnostycznym prowadzącym do implantowania. Uzyskane umiejętności słuchowe pozwalają na powrót do satysfakcjonującego uczestniczenia w życiu społecznym.

\section{Aspekty rehabilitacji pacjentów $\mathrm{z}$ różnego typu implantami słuchowymi}

\author{
Anna Geremek-Samsonowicz, \\ Agnieszka Pankowska, Anna Barej, \\ Joanna Ćwiklińska, Agata Lutek, \\ Anna Charukiewicz, tukasz Olszewski, \\ Henryk Skarżyński
}

Światowe Centrum Słuchu, Instytut Fizjologii i Patologii Stuchu, Warszawa/Kajetany

Słowa kluczowe: implanty słuchowe • rehabilitacja

Wprowadzenie: Światowe Centrum Słuchu Instytutu Fizjologii i Patologii Słuchu stawia sobie za cel organizację specjalistycznej pomocy swoim pacjentom. Zastosowanie implantów słuchowych w leczeniu różnego typu ubytków słuchu stawia przed specjalistami zadanie przygotowania programów rehabilitacji odpowiadających specyficznym potrzebom danej grupy pacjentów. Celem pracy jest przedstawienie krótkiej charakterystyki pacjentów kwalifikowanych do leczenia $\mathrm{z}$ wykorzystaniem implantów słuchowych w tym ucha środkowego, wszczepialnych aparatów na przewodnictwo kostne oraz implantów ślimakowych i odmienności oddziaływań rehabilitacyjnych w zakresie postępowania pooperacyjnego.

Materiał i metody: Materiał to 3915 osób, pacjenci zoperowani w Klinice Otorynolaryngochirurgii Instytutu Fizjologii i Patologii Słuchu do 2013 r., u których wykorzystano implanty słuchowe oraz informacje uzyskane na podstawie badań diagnostycznych i wywiadu na etapie kwalifikacji przedoperacyjnej.

Wnioski: Przedstawione informacje określają aktualne możliwości leczenia różnego typu ubytków słuchu z wykorzystaniem implantów słuchowych oraz wyznaczaja potrzebę kompleksowego spojrzenia na potrzeby pacjentów i organizację opieki pooperacyjnej. Prowadzone postępowanie wskazuje konieczność organizacji rehabilitacji w każdym postępowaniu pooperacyjnym.

\section{Ocena stabilności implantów zakotwiczonych w kości (BAHA) u dzieci $\mathrm{z}$ wadami rozwojowymi twarzoczaszki}

Wiesław Konopka ${ }^{1,2}$, Małgorzata Strużycka ${ }^{1}$, Małgorzata Śmiechura ${ }^{1}$, Renata Pepaś ${ }^{1}$

\footnotetext{
${ }^{1}$ Klinika Otolaryngologii ICZMP

${ }^{2}$ Uniwersytet Medyczny w Lodzi
}

Słowa kluczowe: implanty BAHA • stabilność • dzieci

Celem pracy była, ocena stabilności implantu w zależności od grubości tkanki kostnej, okresu czasu od operacji, jak również rodzaju deformacji twarzoczaszki.

Materiał i metody: Materiał badań stanowiła grupa 14 dzieci w wieku 5-11 lat, w tym 4 dziewczynki i 10 chłopców, u których wykonano 18 zabiegów operacyjnych wszczepienia implantu BAHA. Metodyka obejmowała jednoetapowy zabieg chirurgiczny zarówno z zastosowaniem dermatomu, jak i z cięcia liniowego. U 13 dzieci wszczepiono implant $4 \mathrm{~mm}$, a u jednej osoby $3 \mathrm{~mm}$. Pomiary stabilności implantu przeprowadzono zgodnie z procedurą ISQ. Analizę statystyczną wykonano z zastosowaniem testu Anova. Wartości ISQ rejestrowano, stosując analizę częstotliwości rezonansowej w czasie implantacji i po 1 , 4 tygodniach oraz 3, 6 i 12 miesiącach po zabiegu chirurgicznym. Pomiary grubości kości przeprowadzono podczas zabiegu operacyjnego.

Wyniki: Wady rozwojowe ucha zewnętrznego pod postacią mikrocji i atrezji przewodu słuchowego zewnętrznego występowały u 8 badanych, zespół Treachera-Collinsa u 5 dzieci i zespół skrzelowo-uszno-nerkowy u 1 badanego. W grupie dzieci z zespołem Treachera-Collinsa - wszczepiono 6 implantów, w obustronnych wadach rozwojowych ucha zewnętrznego - 7 implantów, w jednostronnych - 4 implanty z 1 implant w zespole skrzelowo-uszno-nerkowym. Średnia wartość ISQ bezpośrednio po zabiegu wynosiła 52 , po tygodniu - 54, po czterech tygodniach -56 , po trzech miesiącach -55 , po sześciu miesiącach -60 i po roku - 66. W grupie dzieci z mikrocją grubość kości wynosiła średnio od $3 \mathrm{~mm}$ (5 uszu) do $4 \mathrm{~mm}$ (6 uszu), a średnia wartość ISQ w czasie zabiegu wynosiła 58, po tygodniu - 56, cztery tygodnie po operacji - 60, trzy miesiące $-65,6$ miesięcy - 62 i rok po wszczepieniu implantu - 66 . W grupie dzieci z zespołem Treachera-Collinsa stwierdzono grubość kości $3 \mathrm{~mm}$ (dwoje uszu) i $4 \mathrm{~mm} \mathrm{w} 4$ uszach. Grubość kości skroniowej u dziecka z zespołem skrzelowo uszno nerkowym wynosiła $4 \mathrm{~mm}$.

Wnioski: Pomiary stabilności implantu wykazały wysokie średnie wartości ISQ bezpośrednio po zabiegu operacyjnym oraz stopniowy wzrost wartości ISQ w czasie. Stwierdzony poziom osseointegracji implantów u dzieci z wadami rozwojowymi twarzoczaszki 4 tygodnie po implantacji był wystarczający do zamocowania procesora dźwięku. 


\section{Analiza czynników ryzyka uszkodzenia słuchu w populacji osób z głuchotą i znacznego/ głębokiego stopnia uszkodzeniem słuchu w okresie prelingwalnym}

\section{Marzena Mielczarek, Jurek Olszewski}

Klinika Otolaryngologii i Onkologii Laryngologicznej, Uniwersytet Medyczny w Lodzi

Słowa kluczowe: ryzyka uszkodzenia słuchu • prelingwalny głęboki niedosłuch

Wprowadzenie: Celem pracy była analiza czynników ryzyka uszkodzenia słuchu u osób z głuchotą i znacznego/głębokiego stopnia uszkodzeniem słuchu w okresie prelingwalnym.

Materiał i metody: Materiał badań stanowiła grupa 28 pacjentów (w wieku 5-43 lata) z głuchotą lub znacznego/głębokiego stopnia uszkodzeniem słuchu w okresie prelingwalnym. Pacjenci (bądź opiekun prawny) zakwalifikowani do badania wypełnili kwestionariusz pytań dotyczący wywiadu audiologicznego (czynniki ryzyka uszkodzenia słuchu). U wszystkich pacjentów po wyrażeniu pisemnej, świadomej zgody (zgoda pacjenta lub opiekuna prawnego w przypadku osoby niepełnoletniej) wykonano pobranie krwi na badania genetyczne w kierunku identyfikacji uszkodzenia słuchu uwarunkowanego autosomalnie recesywnie. Identyfikowano mutacje w genie koneksyny $26-$ GJB2 (IVS+1 G-A, 310del14, L90P, M34T, V37I, 167 delT, delAA333, delE 120).

Wyniki i wnioski: Mutację w genie GJB2 stwierdzono u 5 badanych (we wszystkich przypadkach była to mutacja 35delG). Nie stwierdzono innych mutacji w tym genie. W 2 przypadkach dodatni wynik badania genetycznego współistniał z wystąpieniem czynnika ryzyka uszkodzenia słuchu - terapia antybiotykami aminoglikozydowymi we wczesnym dzieciństwie. U jednego dziecka stwierdzono mikrouszkodzenia OUN. W pozostałych przypadkach etiologia uszkodzenia słuchu pozostała nieznana.

\section{Analiza czynników ryzyka uszkodzenia słuchu u pacjentów $z$ postlingwalnym uszkodzeniem słuchu}

\section{Marzena Mielczarek, Jurek Olszewski}

Klinika Otolaryngologii i Onkologii Laryngologicznej,

Uniwersytet Medyczny w Łodzi

Słowa kluczowe: ryzyka uszkodzenia słuchu • postlingwalny niedosłuch

Wprowadzenie: Celem pracy była analiza czynników ryzyka uszkodzenia słuchu u pacjentów z postlingwalnym odbiorczym niedosłuchem.

Materiał i metody: Badania przeprowadzono u 50 pacjentów diagnozowanych w Klinice Otolaryngologii i Onkologii Laryngologicznej, u których stwierdzono odbiorcze uszkodzenie słuchu przekraczające normę dla danej grupy wiekowej. U pacjentów wykonano badanie laryngologiczne, diagnostykę audiologiczną, otoneurologiczną i obrazową. Pacjenci wypełnili kwestionariusz pytań dotyczący czynników ryzyka uszkodzenia słuchu. Ponadto u 28 pacjentów po wyrażeniu pisemnej, świadomej zgody wykonano pobranie krwi na badanie genetyczne celem identyfikacji niedosłuchu uwarunkowanego autosomalnie dominująco DFNA9 - identyfikacja mutacji w genie kochliny COCH (P51S, V66G, G87W, V104del, I109N, W117R, A119T, M512T, C542Y).

Wyniki i wnioski: Czynniki ryzyka uszkodzenia słuchu najczęściej występujące $\mathrm{w}$ badanej grupie to: narażenie na hałas (ostry, przewlekły uraz akustyczny), stosowanie w przeszłości antybiotyków aminoglikozydowych lub diuretyków pętlowych (furosemid) oraz uraz głowy. Rodzinne występowanie niedosłuchu zgłosiło 28 pacjentów. W przebadanych przypadkach nie stwierdzono mutacji DFNA9 w genie kochliny $(\mathrm{COCH})$.

\section{Zastosowanie implantu ucha środkowego Vibrant Soundbridge $w$ wadach nabytych i złożonych wadach wrodzonych narządu słuchu}

\author{
Henryk Skarżyński ${ }^{1}$, Marek Porowski ${ }^{1}$, \\ Maciej Mrówka ${ }^{1}$, Łukasz Olszewski ${ }^{1}$, \\ Anna Ratuszniak ${ }^{1}$, Piotr H. Skarżyński ${ }^{1,2,3}$
Światowe Centrum Słuchu, Instytut Fizjologii i Patologii Stuchu, Warszawa/Kajetany
${ }^{2}$ Instytut Narządów Zmysłów, Kajetany
${ }^{3}$ Zakład Diagnostyki i Rehabilitacji Okulistycznej i Narządów Zmysłu, Warszawski Uniwersytet Medyczny, Warszawa

Słowa kluczowe: implant ucha środkowego • Vibrant Soundbridge $\bullet$ wady wrodzone i nabyte ucha

Wprowadzenie: Implanty ucha środkowego stanowią alternatywna metodę leczenia zaburzeń słuchu w zaawansowanych chorobach ucha środkowego, gdy inne sposoby chirurgicznej rekonstrukcji czy też klasyczne aparaty słuchowe $\mathrm{z}$ różnych względów nie mogą być zastosowane. Urządzenia te znajdują zastosowanie również $\mathrm{w}$ wadach wrodzonych dotyczących ucha zewnętrznego, w tym także u dzieci. Celem niniejszej pracy była ocena wyników zastosowania implantu ucha środkowego Vibrant Soundbridge w wadach nabytych i złożonych wadach wrodzonych narządu słuchu u pacjentów dorosłych oraz poniżej 18 roku życia.

Materiał i metody: Przedstawiona grupa pacjentów to osoby $\mathrm{z}$ różnymi wadami nabytymi i wrodzonymi ucha środkowego i zewnętrznego, u których zastosowano leczenie niedosłuchu, wykorzystując Vibrant Soundbridge. Sposoby dostępu do ucha środkowego obejmowały najczęściej zachyłek nerwu twarzowego oraz attykotomię tylną. Przedstawiono różne sposoby umocowania przetwornika na kosteczkach słuchowych, resztkach kosteczek oraz na okienku okrągłym, zalety i wady każdego z nich. 
Przedyskutowano wskazania i ograniczenia zastosowania Vibrant Soundbridge.

Wyniki i wnioski: W zdecydowanej większości przypadków korzyści z tego typu urządzeń są znaczne. Doceniają to pacjenci, u których niemożliwe jest zastosowanie klasycznych wewnątrzprzewodowych aparatów słuchowych $\mathrm{z}$ powodu wad wrodzonych, zwłaszcza atrezji przewodu słuchowego zewnętrznego.

\section{Nowy implant słuchowy CODACS w rehabilitacji słuchu pacjentów z otosklerozą i niedosłuchem mieszanym znacznego stopnia}

\author{
Henryk Skarżyński ${ }^{1}$, Marek Porowski ${ }^{1}$, \\ Maciej Mrówka ${ }^{1}$, Łukasz Olszewski ${ }^{1}$, \\ Piotr H. Skarżyński ${ }^{1,2,3}$

\footnotetext{
${ }^{1}$ Światowe Centrum Stuchu, Instytut Fizjologii i Patologii Stuchu, Warszawa/Kajetany

${ }^{2}$ Instytut Narządów Zmysłów, Kajetany

${ }^{3}$ Zakład Diagnostyki i Rehabilitacji Okulistycznej i Narządów Zmysłu, Warszawski Uniwersytet Medyczny, Warszawa
}

Słowa kluczowe: otoskleroza $\bullet$ niedosłuch mieszany $\bullet$ implant słuchowy $\bullet$ CODACS

Wprowadzenie: Implant słuchowy Codacs stanowi alternatywną metodę rehabilitacji słuchu pacjentów z zaawansowaną otosklerozą i niedosłuchem mieszanym znacznego stopnia. W Polsce po raz pierwszy został on wszczepiony przez prof. Skarżyńskiego 5 pacjentom. Celem niniejszej pracy była ocena wyników zastosowania implantu słuchowego Codacs u pacjentów dorosłych oraz przedstawienie procedury chirurgicznej związanej z tym implantem.

Materiał i metody: Materiał obejmuje 5 dorosłych pacjentów z zaawansowaną otosklerozą i obustronnym niedosłuchem mieszanym znacznego stopnia. Poszczególne etapy operacji obejmowały tympanotomię przednią, antromastoidektomię z tympanotomią tylną, zamocowanie części wewnętrznej implantu wraz ze sztucznym kowadełkiem, stapedotomię z zawieszeniem protezki na sztucznym kowadełku i zamknięcie pola operacyjnego.

Wyniki i wnioski: Wyniki po operacji uzyskane u 4 pacjentów są dobre i bardzo dobre. U jednego pacjenta wyniki były gorsze $\mathrm{z}$ powodu współistniejących zmian wstecznych ośrodkowego układu nerwowego. Resztki słuchowe zostały zachowane u wszystkich pacjentów na poziomie sprzed operacji.

\section{Zastosowanie implantów zakotwiczonych w kości (BAHA) - wyniki odległe}

\author{
Maciej Mrówka ${ }^{1}$, Marek Porowski ${ }^{1}$, \\ Anna Ratuszniak ${ }^{1}$, tukasz Olszewski, \\ Henryk Skarżyński ${ }^{1}$, Piotr H. Skarżyński ${ }^{1,2,3}$ \\ ${ }^{1}$ Światowe Centrum Słuchu, Instytut Fizjologii i Patologii \\ Stuchu, Warszawa/Kajetany \\ ${ }^{2}$ Instytut Narządów Zmysłów, Kajetany \\ ${ }^{3}$ Zakład Diagnostyki i Rehabilitacji Okulistycznej i Narządów \\ Zmystu, Warszawski Uniwersytet Medyczny, Warszawa
}

Słowa kluczowe: implanty zakotwiczone w kości • BAHA - mikrocja • niedosłuch przewodzeniowy i mieszany

Wprowadzenie: Niedosłuch przewodzeniowy i mieszany przy obustronnej mikrocji $\mathrm{z}$ atrezją przewodu słuchowego lub po przewlekłym zapaleniu ucha środkowego można leczyć z użyciem implantów zakotwiczonych w kości BAHA. Celem pracy była ocena wpływu zastosowania różnych metod chirurgicznych wszczepienia zaczepów tytanowych na pooperacyjne gojenie rany i występowanie wczesnych i odległych reakcji skórnych wymagających interwencji chirurgicznej.

Materiał i metody: Materiał obejmuje 124 pacjentów w wieku 3-67 lat. Naszą metodą z wyboru w omawianych przypadkach jest umieszczenie tytanowego implantu w kości skroniowej z redukcją tkanki podskórnej. Stosowane są 3 techniki nacięcia skóry: U-graft, dermatom i nacięcie w linii prostej. Tkanka wokół zaczepu była pocieniana bez pobierania płata skóry. Urządzenie było ustawiane po wygojeniu rany i osseointegracji zaczepów (6 tyg. - 6 mies. zależnie od grubości kości, długości zaczepów, jedno- lub dwuetapowej techniki chirurgicznej i stanu rany). Do oceny reakcji tkanek miękkich wokół implantów przezskórnych użyto powszechnie przyjętą klasyfikację reakcji skórnych Holgersa. W przypadkach poważnych infekcji (stopień 4 według skali Holgersa) przeprowadzano reoperację.

Wyniki: Wykonano 17 reoperacji z powodu zapalnej reakcji skóry w miejscu wszczepu (stopień 4), z czego u 15 pacjentów pierwotna operacja była wykonana techniką U-graft, u jednego techniką dermatomu i jednego po nacięciu w linii prostej. Technika wykonania nacięcia skóry wpływa w istotny sposób na występowanie konieczności reoperacji ( $\mathrm{p}=0,00167)$. W grupie pacjentów po nacięciu w linii prostej lub technice U-graft prawie $20 \%$ pacjentów wymagało reoperacji, w grupie pacjentów operowanych techniką dermatomu reoperacja była konieczna w niewiele ponad $2 \%$ przypadków.

Wnioski: Ocena wpływu wybranej techniki wszczepienia zaczepu tytanowego na gojenie rany po operacji i wczesne oraz odległe reakcje skórne pokazuje, że najlepsze wyniki można osiągnąć, stosując technikę dermatomu. 


\section{Zastosowanie implantów wykorzystujących kostne przewodnictwo dźwięków Med-El Bonebridge u dorosłych pacjentów Z wrodzoną lub nabytą utratą słuchu - pierwsze doświadczenia}

\author{
Maciej Mrówka ${ }^{1}$, Marek Porowski ${ }^{1}$, \\ Anna Ratuszniak ${ }^{1}$, Łukasz Olszewski ${ }^{1}$, \\ Henryk Skarżyński ${ }^{1}$, Piotr H. Skarżyński ${ }^{1,2,3}$ \\ ${ }^{1}$ Światowe Centrum Słuchu, Instytut Fizjologii i Patologii \\ Stuchu, Warszawa/Kajetany \\ ${ }^{2}$ Instytut Narządów Zmysłów, Kajetany \\ ${ }^{3}$ Zakład Diagnostyki i Rehabilitacji Okulistycznej i Narządów \\ Zmystu, Warszawski Uniwersytet Medyczny, Warszawa
}

Słowa kluczowe: implanty słuchowe - przewodnictwo kostne • Bonebridge

Wprowadzenie: Med-El Bonebridge jest nowym aktywnym implantem wykorzystującym zjawisko kostnego przewodzenia dźwięków. Może być stosowany u dorosłych pacjentów z utratą słuchu różnego pochodzenia - wrodzoną lub nabytą. Urządzenie to umożliwia przenoszenie dźwięku bezpośrednio do ucha wewnętrznego z pominięciem niedorozwiniętego lub uszkodzonego przez proces zapalny ucha środkowego. Celem pracy jest przedstawienie pierwszych doświadczeń i dyskusji na temat techniki operacyjnej u pacjentów $\mathrm{z}$ ubytkiem słuchu, u których zastosowano implant kostny typu Bonebridge.

Material i metody: Materiał pracy obejmuje 16 pacjentów operowanych w latach 2012-2014. Część wewnętrzna implantu Bonebridge jest umieszczana pod skórą w specjalnej loży kostnej i fiksowana za pomocą dwóch krótkich śrub osteointegracyjnych. Czas operacji nie przekracza 1 godziny.

Wyniki: Podczas zabiegów oraz w okresie pooperacyjnym nie zaobserwowano poważnych powikłań, jednak należy nadmienić że ze względu na dość duże rozmiary przetwornika kostnego $(8,3 \mathrm{~mm})$ wymagana jest przedoperacyjna ocena możliwości zastosowania ww. implantu dokonywana na podstawie analizy zdjęć tomografii komputerowej głowy.

Wnioski: Pierwsze doświadczenia są bardzo zachęcające. $\mathrm{W}$ opinii autorów, to rozwiązanie jest bardzo obiecujące, gdyż daje duże wzmocnienie przekładające się na poprawienie rozumienia mowy u pacjenta. Jednocześnie jest pozbawione elementów przezskórnych, które mogą powodować stany zapalne tkanek otaczających.
Kwalifikacja i konsultacje przed wszczepem implantu ślimakowego u osób starszych

\section{Magdalena Lachowska, Agnieszka Pastuszka, Zuzanna Lukaszewicz, Lidia Mikołajewska, Kazimierz Niemczyk}

Katedra i Klinika Otolaryngologii, Warszawski Uniwersytet Medyczny

Słowa kluczowe: implant ślimakowy • niedosłuch odbiorczy

Konwencjonalne aparaty słuchowe skutecznie kompensują różne stopnie ubytku słuchu, z wyjątkiem przypadków niedosłuchu stopnia znacznego i głębokiego, w których nawet najbardziej zaawansowane aparaty słuchowe mogą nie być wystarczające. Tak głęboki niedosłuch zazwyczaj prowadzi do izolacji społecznej i niekiedy do depresji. W tych przypadkach implant ślimakowy wydaje się być najlepszym rozwiązaniem. Wyniki uzyskiwane przez naszych pacjentów i te prezentowane w literaturze potwierdzają, że osoby starsze sa dobrymi kandydatami do wszczepu ślimakowego jako metody leczenia głuchoty. Niemniej grupa ta nie jest homogeniczna i każdy kandydat powinien być poddany wnikliwej procedurze kwalifikacyjnej. W prezentowanej pracy omawiane będą wyzwania, jakie stawia przed Zespołem Implantów Ślimakowych kwalifikacja i konsultacje osób starszych zgłaszających się jako potencjalni kandydaci do implantacji ślimakowej.

\section{Wpływ implantacji ślimakowej na równowagę funkcjonalną ciała}

Agnieszka Kargul', Grzegorz Juras', Jan Pilch ${ }^{1}$, Małgorzata Witkowska ${ }^{2}$, Lucyna Klimczak-Gołąb ${ }^{2}$, Jarosław Markowski

\footnotetext{
${ }^{1}$ Akademia Wychowania Fizycznego im. J. Kukuczki, Katowice

${ }^{2}$ Samodzielny Publiczny Szpital Kliniczny im. A. Mielęckiego, Śląski Uniwersytet Medyczny w Katowicach
}

Słowa kluczowe: implant ślimakowy • równowaga funkcjonalna $\bullet$ głuchota $\bullet$ posturografia

Wprowadzenie: Zaburzenia równowagi stanowią obecnie duży problem medyczny, ekonomiczny i społeczny. Zmniejszona zdolność do adaptacji ciała na różnego rodzaju bodźce może być przyczyną zwiększonej podatności na upadki. Implanty ślimakowe są obecnie bezpieczną i szeroko stosowaną metodą leczenia osób z głuchotą. Doświadczenie kliniczne pokazuje jednak, że fakt implantacji może być przyczyną nowych zaburzeń posturalnych. Celem badania była ocena wpływu implantacji ślimakowej na równowagę ciała.

Materiał i metody: Grupę kliniczną (K) stanowiło 14 pacjentów po implantacji ślimakowej (wiek: $31,78 \pm 11,78$ ). W celach porównawczych do badania włączono dwie grupy kontrolne osób bez zaburzeń słuchu: młodszą (M) $(\mathrm{n}=16) \mathrm{w}$ wieku $19,31 \pm 0,60$ i starszą $(\mathrm{S})(\mathrm{n}=15)$ w wie-

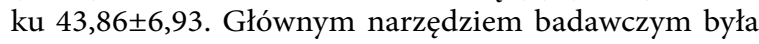


platforma dynamograficzna AccuGait firmy AMTI $(50 \mathrm{~Hz})$. Do oceny równowagi funkcjonalnej ocenianej testem maksymalnego wychylenia (ang. Maximal Voluntary Leaning - MVL) wykorzystano program MatLab, a następnie Helter 6.0. Za podstawowy parametr MVL posłużył rozstęp (R2), będący dystansem pomiędzy średnią trajektorią COP w fazie stania swobodnego a końcową fazą maksymalnego wychylenia w płaszczyźnie strzałkowej. Za drugi parametr przyjęto współczynnik kierunkowy regresji (B2), opisujący bezpośrednio szybkość wychylenia badanej osoby.

Wyniki: Wykazano brak wpływu włączenia implantu na równowagę funkcjonalną badanej grupy K. Podczas wychyleń nie stwierdzono istotnych różnic statystycznych, pomiędzy badanymi grupami K, M oraz ST, dotyczących wartości rozstępu (R2). Po porównaniu współczynników regresji B stwierdzono we wszystkich wychyleniach (przód, tył, lewo, prawo) statystycznie znamienne szybsze wychylenie grupy K oraz grupy osób ST w porównaniu do grupy osób $\mathrm{M}$.

Wnioski: Osoby z wszczepionym implantem ślimakowym są w stanie utrzymywać równowagę ciała ocenianą poprzez funkcjonalny test maksymalnego wychylenia w sposób nieodbiegający od badanych osób zdrowych.

\section{Sesja VI • Szkoleniowa}

\section{Nowe metody diagnostyki audiologicznej}

\section{Magdalena Lachowska}

Katedra i Klinika Otolaryngologii, Warszawski Uniwersytet Medyczny

Słowa kluczowe: słuchowe potencjały stanu quasi ustalonego $\bullet$ otoemisje akustyczne wywołane tonem typu swept

Metoda słuchowych potencjałów stanu quasi ustalonego (QASSR) pozwala na jednoczasową rejestrację dwóch różnych technik pomiarów elektrofizjologicznych wykorzystywanych do oceny narządu słuchu, potencjalnie niemożliwych do rejestracji jednoczasowej: potencjałów przejściowych (transient $\mathrm{ABR} / \mathrm{MLR}$ ) i potencjałów stanu ustalonego (ASSR). QASSR pozwala na wyznaczenie progów słyszenia $\mathrm{z}$ bardzo dobrą dokładnością (w granicach do 5-6 dB różnicy w stosunku do progów behawioralnych w audiometrii tonalnej) zarówno u osób ze słuchem prawidłowym, jak i niedosłuchem. Metoda otoemisji akustycznych wywołanych $\mathrm{z}$ zastosowaniem tonu typu HLeqSwept umożliwia rejestrację odpowiedzi OAE nawet $\mathrm{z}$ zastosowaniem małych natężeń bodźca. HLeqsTEOAE pozwala na rejestrację odpowiedzi TEOAE u osób z prawidłowym słuchem i nierejestrowalnym TEOAE z zastosowanie bodźca typu trzask. Metoda ta potencjalnie oferuje możliwość oceny progu słyszenia. Zaprezentowane zostaną metody stymulacji i akwizycji sygnału obu wymienionych metod, interpretacja wyników i możliwości ich wykorzystania w diagnostyce audiologicznej.
Sesja VIII • Szumy uszne, zawroty głowy

\section{Jakość życia dzieci i młodzieży głuchej i niedosłyszącej w wieku 8-18 lat}

\section{Paulina Kowalska, Anna Pajor, Tomasz Durko}

Uniwersytecki Szpital Kliniczny nr $1 \mathrm{im}$. Norberta Barlickiego, Uniwersytet Medyczny $w$ Łodzi

Słowa kluczowe: jakość życia • HRQOL • dzieci głuche • dzieci niedosłyszące

Wprowadzenie: Niedosłuch, prowadząc do opóźnienia rozwoju mowy, niesie wiele zagrożeń dla rozwoju psychofizycznego dziecka, w tym do zaburzeń w sferze poznawczej, emocjonalnej i społecznej. Celem pracy było określenie czynników związanych z jakością życia dzieci i młodzieży z wadami słuchu.

Materiał i metody: Badaniami objęto grupę 108 dzieci i młodzieży w wieku 8-18 lat, z 3 ośrodków szkolno-wychowawczych dla osób głuchych i niedosłyszących z terenu Łodzi. Narzędziem badawczym był kwestionariusz Kidscreen-52, czyli formularz masowych badań HRQOL dla dzieci i młodzieży w wieku 8-18 lat, oraz autorski kwestionariusz do oceny wpływu niepełnosprawności narządu słuchu na funkcjonowanie osób badanych (KOWNNS).

Wyniki: Stopień upośledzenia słuchu nie okazał się związany z subiektywną oceną jakości życia. Uzyskane wyniki pozwalają stwierdzić, że płeć jest istotnym statystycznie czynnikiem moderującym wpływ stopnia upośledzenia słuchu na jakość życia w zakresie zadowolenia $\mathrm{z}$ siebie i swojego wyglądu; wykazały także zależność pomiędzy postępującym upośledzeniem słuchu, współistniejącymi problemami zdrowotnymi i dostępem do specjalistycznej opieki medycznej (w tym psychologa i logopedy) a jakością życia. Wiek aparatowania oraz jego rodzaj, aktywność fizyczna zostały także potwierdzone jako czynniki wpływające na jakość życia badanej grupy.

Wnioski: Dzieci i młodzież głucha i niedosłysząca w wieku 8-18 lat mają istotnie gorszą jakość życia w wymiarach: Zdrowie fizyczne, Zasoby finansowe, Postrzeganie siebie i Akceptacja społeczna w porównaniu do norm dla populacji polskiej. Wczesne aparatowanie istotnie wpływa na jakość życia. Płeć warunkuje wpływ stopnia upośledzenia słuchu na jakość życia w zakresie zadowolenia z siebie i swojego wyglądu. Istnieje związek między intensywnym uprawianiem sportu a zadowoleniem z sytuacji szkolnej. Korzystanie z usług logopedyczno-psychologicznych istotnie wpływa na jakość życia w zakresie relacji z rodzicami, zadowolenia $\mathrm{z}$ sytuacji finansowej. 


\section{Problemy edukacyjne a centralne procesy słuchowe u dzieci}

\section{Małgorzata M. Topolska ${ }^{1}$, Anna Z. Gregorek ${ }^{2}$}

\author{
${ }^{1}$ Klinika Otolaryngologii Dziecięcej UMB \\ ${ }^{2}$ Powiatowa Poradnia Psychologiczno-Pedagogiczna, Białystok
}

Słowa kluczowe: centralne procesy słuchowe • problemy edukacyjne

Badaniami objęto 30 dzieci z problemami w nauce znajdujących się pod opieką białostockich Poradni Psychologiczno-Pedagogicznych. Po badaniu przesiewowym DDT (test uwagi rozproszonej oraz test uwagi ukierunkowanej) wykonanym w Poradni Psychologiczno-Pedagogicznej dzieci były diagnozowane audiologicznie w Klinice Otolaryngologii Dziecięcej w Białymstoku. Wykonano podstawowe badania audiologiczne - audiogram i audiometrię impedancyjną oraz badania oceniające centralne procesy percepcji słuchowej: testy mową o niskiej redundancji test liczbowy z ograniczonym pasmem do $1 \mathrm{kHz}$ (LICZ), test zdaniowy - mowa skompresowana o 60\% (ZD 60\%) i 40\% (ZD 40\%) oraz badanie różnicowania częstotliwości dźwięków FPT (1 i 4 kHz) oraz różnicowania długości trwania dźwięków DPT. Do wyników badań audiologicznych odniesiono ocenę pedagogiczno-psychologiczną, poszukując korelacji między poszczególnymi testami audiologicznymi a problemami edukacyjnymi badanych dzieci. Porównano grupy dzieci $z$ deficytem i prawidłową analizą słuchową, syntezą słuchową, pamięcią fonologiczną i różnicowaniem głosek. Grupa z deficytem analizy słuchowej wykazywała gorszą uwagę ukierunkowaną zarówno UP, jak i UL oraz znaczne zaburzenia w teście liczbowym z ograniczonym pasmem częstotliwości. Grupa z deficytem syntezy słuchowej charakteryzowała się gorszą uwagą ukierunkowaną w UP i lepszą uwagą ukierunkowaną w UL, w grupie tej występowało lepsze różnicowanie FPT i DPT. Grupa z deficytem pamięci fonologicznej - wszystkie badania oceniające centralne procesy słuchowe wypadły gorzej w odniesieniu do grupy z prawidłową pamięcią fonologiczną. Grupa z deficytem różnicowania głosek - gorsza uwaga ukierunkowana i rozproszona w UP, nieprawidłowa analiza mowy skompresowanej $60 \%$ oraz gorsze różnicowanie FPT i DPT.

\section{Objawy audiologiczne w wybranych chorobach neurologicznych}

\section{Tomasz Przewoźny, Dariusz Gąsecki, Walenty Nyka}

Katedra i Klinika Otolaryngologii, Gdański Uniwersytet Medyczny

Słowa kluczowe: stwardnienie rozsiane • udar niedokrwienny mózgu • padaczka • niedosłuch odbiorczy • nagła głuchota $\bullet$ szumy uszne

Wprowadzenie: Wśród objawów chorób układu nerwowego na plan pierwszy wysuwają się dolegliwości związane z uszkodzeniem ośrodków ruchowych i czuciowych centralnego układu nerwowego, czego objawami najczęściej są niedowłady, porażenia, afazja oraz zaburzenia widzenia i równowagi. Ocena słuchu chorego schodzi na drugi plan, często z uwagi na ciężki stan ogólny i potrzebę pilnego, intensywnego leczenia neurologicznego. Autorzy podjęli próbę przedstawienia problemu zaburzeń narządu słuchu u chorych neurologicznych.

Materiał i metody: Autorzy przedstawiali wyniki badań audiologicznych wybranych chorych z grupy 84 diagnozowanych w naszym ośrodku, leczonych $\mathrm{z}$ powodu najczęstszych jednostek chorobowych spotykanych w klinikach neurologii (stwardnienie rozsiane, udar niedokrwienny mózgu, padaczka). Dokonano korelacji badań słuchu (audiometria tonalna, słowna, impedancyjna, emisje otoakustyczne, słuchowe potencjały wywołane pnia mózgu, badanie kąta ostrości słyszenia kierunkowego) ze stanem neurologicznym chorych i obrazami uszkodzeń tkanki nerwowej w badaniach radiologicznych.

Wyniki: Autorzy zwrócili uwagę na częstość występowania u tych chorych nagłej głuchoty, niedosłuchu, szumów usznych, zaburzeń wyższych czynności słuchowych, podejmując próbę wyjaśnienia ich występowania.

Wnioski: Objawy audiologiczne chorób układu nerwowego nie są częstym objawem w tej grupie schorzeń, będąc często pomijanymi w badaniu przedmiotowym. Pojawiają się na drodze bezpośredniego uszkodzenia drogi słuchowej wewnątrz mózgu, zmian niedokrwiennych ślimaka lub na drodze zaburzeń zwrotnych mechanizmów nerwowych ślimaka.

\section{Assessment of functional surgery at chronic otitis media}

\section{Oleg Khorov, Ekatyrina Golovach}

Grodno State Medical University, Grodno, Białoruś

Słowa kluczowe: middle ear • audiological results • tympanoplasty $\bullet$ chronic otitis media

In the range of different factors which subject an ear to postoperative strength test there is a problem of retraction processes and disorders of the middle ear cavity ventilation. Purpose: 1) present method of surgical technic for the prevention of retractions and tympanosclerotic processes, 2) estimate the efficiency of the method of kinesiotherapy of the pharyngeal muscles (KMP). We performed for the prevention of violations of ventilation in the middle ear during the operation. We used for reconstruction tympanic membrane two-layer rag consist of cartilage and fascia, or perihondrium. The cartilaginous plate consisted of mobile fragments. We have carefully formed front corner. We formed way in the middle ear ventilation for all spaces. The patients carried out kinesiotherapy of the pharyngeal muscles in preoperative and postoperative period. The patients carried out KPM consisting of 10 exercises. Positive clinical and morphological result depended on the volume of reconstruction. The number of patients with adequate social hearing after closed tympanoplasty increased from 
$42.6 \%$ to $86.5 \%$ (1 type), from $40 \%$ to $69 \%$ (attikoantrotomy with tympanoplasty), after open tympanoplasty from $22.2 \%$ to $61.5 \%$. The control of tympanogrammes established larger increase of indicators $\mathrm{P}, \mathrm{G}, \mathrm{C}$ after carried out KPM repeatedly P on $24, \mathrm{G}$ on 0.014 , C on 0.05 .

Conclusion: During the reconstruction of the middle ear it is necessary to attach importance to the formation of neotympanic cavity's walls for creation of resistant aer system. In the postoperative period, measures for maintenance of ventilation of the middle ear are needed. Kinesiotherapy of throat muscles is a simple and available method, which can be performed by the patient under control of ENT-doctor.

\section{Niedosłuch centralny - nowe wyzwania dla procesu rehabilitacji}

\section{Iwona Sosnowska-Wieczorek}

Centrum Diagnostyki i Terapii In Corpore, Katowice

Wraz z postępami osiąganymi w medycynie oraz technologii medycznej zmienia się rzeczywistość diagnostyczna, terapeutyczna i edukacyjna dzieci niepełnosprawnych. Szczególną grupę w tym zakresie stanowią dzieci z niepełnosprawnością słuchową. Problemy ze słuchem nie ograniczają się do zaburzeń słuchu spowodowanymi uszkodzeniami ucha środkowego, wewnętrznego, nerwu słuchowego i pnia mózgu. Trudności w korzystaniu ze słuchu powodują także zaburzenia procesów przetwarzania dźwięków, które zachodzą w wyższych piętrach ośrodkowego układu słuchowego.

W procesie diagnostycznym audiolog powinien ściśle współpracować z logopedą, pedagogiem i psychologiem, by mieć pełny obraz kliniczny pacjenta. Diagnoza audiologiczna stanowi punkt wyjścia do zorganizowania dziecku zaplecza pomocowego oraz edukacyjnego. Na jej podstawie komisje do spraw orzekania o niepełnosprawności wydają orzeczenia o niepełnosprawności dziecka, co umożliwia między innymi refundację oprotezowania centralnego czy też rozpoczęcie rehabilitacji medycznej. Ta sama diagnoza audiologiczna stanowi punkt wyjścia do wdrożenia procedury objęcia ucznia kształceniem specjalnym w szkole i rozpoczęcia systematycznej rehabilitacji, która wzmacniana innowacyjnymi metodami pracy daje spektakularne efekty terapeutyczne.

\section{Rola lekarza - specjalisty audiologa i foniatry jako konsultanta specjalisty medycyny pracy oraz jako biegłego sądowego}

Ryszard Szozda

\section{7 maja 2014 r., sobota}

\section{SALA C • Sesja XII • Logopedyczna}

\section{Diagnoza różnicowa dysfazji rozwojowej i niedosłuchu centralnego}

\section{Olga Przybyla ${ }^{1}$, Katarzyna Kasica-Bańkowska ${ }^{2}$}

\footnotetext{
${ }^{1}$ Centrum Logopedii i Audiodeskrypcji, Uniwersytet Śląski $w$ Katowicach

${ }^{2}$ Specjalistyczny Ośrodek Diagnozy i Rehabilitacji dla Dzieci i Młodzieży $z$ Wada Stuchu PZG, Katowice
}

Zajmując się zagadnieniami diagnozy oraz terapii zaburzeń rozwoju mowy i zakłóceń słownego procesu komunikowania, często spotykamy się z heterogennością zaburzeń nazywanych SLI (Specyfic Language Impairment). Badając dzieci baterią testów językowych, szacujących procesy przetwarzania fonologicznego, i innymi specjalistycznymi procedurami audiometrycznymi, próbujemy ocenić możliwości językowe i komunikacyjne dziecka oraz zaszeregować je do danej grupy zaburzeń. Często dużym problemem staje się diagnoza różnicowa dysfazji rozwojowej i niedosłuchu centralnego. Niniejsza prezentacja skupia się na odnalezieniu przyczyn trudności słuchowych i językowych w wyżej wymienionych deficytach rozwojowych oraz na sposobie percepcji mowy w odniesieniu do czasowych aspektów przetwarzania słuchowego niezbędnych m.in. przy dyskryminacji fonemów.

\section{Sesja XIII}

\section{Czasowo-częstotliwościowa analiza emisji otoakustycznych zmierzonych u noworodków}

\section{Wiesław Wiktor Jędrzejczak ${ }^{1}$, Piotr H. Skarżyński ${ }^{1}$, Stavros Hatzopoulos², Henryk Skarżyński ${ }^{1}$ \\ ${ }^{1}$ Światowe Centrum Stuchu, Instytut Fizjologii i Patologii Stuchu, Warszawa/Kajetany \\ ${ }^{2}$ ENT Department, University Hospital of Ferrara, Ferrara, Włochy}

Słowa kluczowe: CEAOE • analiza czasowo-częstotliwościowa

Wprowadzenie: Najpopularniejszy sposób pomiaru emisji otoakustycznych wywołanych trzaskiem (CEAOE) to tzw. protokół nieliniowy. Celem niniejszej pracy było porównanie czasowo-częstotliwościowych właściwości CEOAE zmierzonych za pomocą protokołu nieliniowego z CEAOE zmierzonymi za pomocą protokołu liniowego i przesiewowego (QuickScreen).

Materiał i metody: CEOAE zostały zmierzone w grupie noworodków. Stosowano trzy protokoły: nieliniowy, liniowy i przesiewowy. Dla protokołów nieliniowego i liniowego 
długość okna pomiarowego wynosiła $20 \mathrm{~ms}$, podczas gdy dla przesiewowego wynosiła $12 \mathrm{~ms}$. Wszystkie zmierzone sygnały poddano analizie czasowo-częstotliwościowej. W przypadku CEOAE zmierzonych za pomocą protokołu liniowego zastosowano dodatkową procedurę usuwania artefaktów, które zwykle pojawiają się na początku tego sygnału.

Wyniki: CEOAE zmierzone za pomocą protokołów przesiewowych zawierały tylko część odpowiedzi i czasowo-częstotliwościowa struktura sygnału była zaburzona. Analiza poziomu odpowiedzi i stosunku sygnału do szumu (SNR) wykazała, że odpowiedzi zmierzone za pomocą protokołu liniowego miały najwyższy SNR.

Wnioski: Wyniki wskazują, że protokoły przesiewowe o skróconym oknie mogą być stosowane jedynie do detekcji emisji. Gdy z CEOAE zmierzonych protokołem liniowym usunięte zostaną artefakty, odpowiedzi te charakteryzują się większym stosunkiem sygnału do szumu niż odpowiedzi zmierzone za pomocą standardowo stosowanego protokołu nieliniowego.

\section{Emisje otoakustyczne o niskiej częstotliwości mierzone u dzieci}

\section{Wiesław Wiktor Jędrzejczak, Krzysztof Kochanek, Lech Śliwa, Edyta Piłka, Anna Piotrowska, Henryk Skarżyński}

Światowe Centrum Stuchu, Instytut Fizjologii i Patologii Stuchu, Warszawa/Kajetany

\section{Słowa kluczowe: CEOAE • TBOAE}

Wprowadzenie: Emisje otoakustyczne u dzieci są dobrym wyznacznikiem funkcji słyszenia w zakresie częstotliwości 1,5-4 kHz. W niniejszej pracy, wykorzystując dwa komercyjne urządzenia, zbadano przydatność emisji w zakresie niskich częstotliwości $0,5-1 \mathrm{kHz}$.

Materiał i metody: Mierzono emisje otoakustyczne (OAE) u dzieci w wieku szkolnym. Pomiary wykonano za pomocą systemów ILO 292 (Otodynamics) oraz HearId (Mimosa Acoustics). Na każdym z urządzeń wykonano dwa pomiary: pierwszy - stosując trzask o poziomie $80 \mathrm{~dB}$ pSPL (CEOAE), drugi - stosując krótki ton o częstotliwości $0,5 \mathrm{kHz}$, również o poziomie $80 \mathrm{~dB}$ pSPL (TBOAE). Półoktawowe wartości poziomu odpowiedzi i stosunku sygnału do szumu (SNR) były poddane dalszej analizie. Wykonano również badania audiometrii tonalnej i impedancyjnej.

Wyniki: Wyniki SNR były podobne dla obydwu urządzeń, zarówno dla trzasków jak i krótkich tonów. Natomiast poziomy odpowiedzi były nieznacznie wyższe dla trzasków dla systemu ILO. Dla krótkich tonów o częstotliwości $0,5 \mathrm{kHz}$ obydwa urządzenia zmierzyły stosunkowo słabe odpowiedzi dla częstotliwości $0,5 \mathrm{kHz}$, a maksimum odpowiedzi było przesunięte do $0,7-1 \mathrm{kHz}$. W większości przypadków SNR dla CEOAE były na poziomie $10 \mathrm{~dB}$ w zakresie $1-4 \mathrm{kHz}$, a SNR dla $0,5 \mathrm{kHz}$ TBOAE były na poziomie $10 \mathrm{~dB}$ w zakresie $0,7-1 \mathrm{kHz}$.
Wnioski: $0,5 \mathrm{kHz}$ TBOAE mogą być zmierzone u dzieci z podobną efektywnością do CEOAE. Mogą zapewnić dodatkową informacje o zakresie częstotliwości 0,7-1 kHz. W tym zakresie CEOAE u dzieci są z reguły nieobecne albo bardzo słabe.

\section{Otoemisje wywołane trzaskiem u osób palących i niepalących}

\author{
Magdalena Koziel ${ }^{1,2}$, \\ Wiesław Wiktor Jędrzejczak ${ }^{1}$, \\ Krzysztof Kochanek ${ }^{1}$, \\ Karolina Dajos-Krawczyńska ${ }^{1}$
${ }^{1}$ Światowe Centrum Słuchu, Instytut Fizjologii i Patologi Stuchu, Warszawa/Kajetany
${ }^{2}$ Centrum Stuchu i Mowy, Kajetany

Słowa kluczowe: palenie tytoniu • otoemisje wywołane trzaskiem (TEOAE) • średnia amplituda otoemisji • stosunek sygnału do szumu (SNR)

Wprowadzenie: Niniejsze badania miały na celu określenie, w jaki sposób palenie papierosów wpływa na wyniki otoemisji wywołanych trzaskiem (TEOAE).

Materiał i metody: Zbadano 20 osób palących, w tym 10 kobiet oraz 10 mężczyzn, oraz 20 osób niepalących, 10 kobiet oraz 10 mężczyzn, w wieku od 19 do 30 lat. Ocenie poddano wyniki średniej amplitudy oraz stosunku sygnału do szumu (SNR) otoemisji dla poszczególnych częstotliwości w badanych grupach.

Wyniki: Analiza uzyskanych wyników wykazała, że dla większości rozpatrywanych częstotliwości nie ma istotnych statystycznie różnic pomiędzy średnią amplitudą otoemisji w uchu prawym dla grupy osób palących i niepalących. Jedynie dla częstotliwości $2 \mathrm{kHz}(\mathrm{p}<0,001)$ oraz $2,8 \mathrm{kHz}$ $(\mathrm{p}<0,04)$ zaobserwowano istotnie statystycznie niższe poziomy amplitudy sygnału w grupie osób palących w porównaniu do osób niepalących. Natomiast w uchu lewym jedynie na częstotliwości $2,8 \mathrm{kHz}(\mathrm{p}<0,02)$ zaobserwowano istotnie statystycznie różnice pomiędzy badanymi grupami. Na tej częstotliwości uzyskano niższe średnie poziomy sygnału amplitudy otoemisji u osób palących. W przypadku analizy stosunku sygnału do szumu (SNR) w uchu lewym istotne statystycznie różnice wystąpiły dla częstotliwości $2,8 \mathrm{kHz}(\mathrm{p}<0,04)$ natomiast w uchu prawym dla częstotliwości dla częstotliwości $1 \mathrm{kHz}(\mathrm{p}<0,02)$. Na tych częstotliwościach $\mathrm{w}$ grupie osób palących obserwowano niższe poziomy SNR.

Wnioski: Palenie papierosów wpływa nieznacznie na obniżenie średnich amplitud oraz SNR otoemisji w grupie młodych osób palących w porównaniu do osób niepalących. 


\section{Ocena dominacji półkulowej dla funkcji językowych, $\mathrm{z}$ wykorzystaniem obrazowania metodą funkcjonalnego rezonansu magnetycznego (fMRI)}

Tomasz Wolak, Agnieszka Pluta, Joanna Wójcik, Katarzyna Cieśla, Monika Lewandowska, Mateusz Rusiniak, Henryk Skarżyński

Światowe Centrum Słuchu, Instytut Fizjologii i Patologii Stuchu, Warszawa/Kajetany

Słowa kluczowe: lateralizacja • funkcje językowe • fMRI

Wprowadzenie: Asymetria funkcjonalna, zwana inaczej lateralizacją czynności, przejawia się dominacją jednej ze stron ciała w wykonywaniu różnych funkcji i wykształca się we wczesnym dzieciństwie. O ile behawioralnie można ocenić dominację ręczności, nożności, oka czy ucha to trudno jest ocenić dominację funkcji związanych $\mathrm{z}$ recepcją i produkcją mowy. Ocena dominacji półkulowej dla funkcji mowy ma bardzo duże znaczenie w wielu terapiach związanych między innymi z dysleksją czy afazją. Równie duże znaczenie ma w przypadku leczenia operacyjnego pacjentów z guzami lub padaczką oporną na leczenie farmakologiczne. Niniejsza praca ma na celu porównanie różnych testów fonetycznej i semantycznej fluencji słownej do badania dominacji półkulowej dla funkcji mowy przeznaczonych do mapowania obszaru Broca oraz testów rozumienia mowy do mapowania obszaru Wernickego.

Materiał i metody: Badania przeprowadzono z udziałem 15 ochotników w skanerze Magnetom Trio 3T. Dla każdej z badanych osób została opracowana indywidualna mapa czynnościowa kory mózgowej z wykorzystaniem pakietu SPM12. Ponadto w czasie badania rejestrowano aktywność w wybranych obszarach w czasie rzeczywistym w celu obserwacji zmian w sygnale BOLD. Każda $\mathrm{z}$ badanych osób miała przeprowadzony dokładny profil lateralizacji z w wykorzystaniem testów behawioralnych.

Wyniki: Podczas obu zadań wykonywanych w czasie badania zaobserwowano aktywność ośrodków związanych z przetwarzaniem językowym, przy czym większą aktywność wykazywał ośrodek Broca. Wśród osób leworęcznych 6/10 wykazało dominację lewej półkuli, 3/10 organizację mieszaną, a 1 osoba prawopółkulową. W grupie osób praworęcznych 3/5 wykazało dominację lewopółkulową, a 2 osoby organizację mieszaną.

Wnioski: Najlepsze rezultaty osiągnięto, wykorzystując test polegający na generowaniu czasowników do prezentowanych rzeczowników. Badania fMRI wykazały, że ręczność nie jest dobrym predyktorem dla dominacji półkulowej funkcji językowych.

\section{Stosowanie przeszczepu komórek tłuszczowych u pacjentów $z$ jednostronnym niedowładem krtani po operacji tarczycy}

\section{Jan Aleszczyk, Oleh Chorow, Igor Odnokozow}

Uniwersytet Medyczny, Grodno, Białoruś

Słowa kluczowe: przeszczep komórek tłuszczowych • jednostronny niedowład krtani

Wstęp: Rehabilitacja pacjentów z jednostronnym niedowładem krtani po operacji tarczycy jest ważna dla Republiki Białoruś, w związku z wypadkiem w elektrowni jądrowej w Czarnobylu. Oferujemy najbardziej fizjologiczną i skuteczną metodę rehabilitacji tych pacjentów - przeszczep komórek tłuszczowych. Sposób ten ma istotne zalety w stosunku do wszczepiania substancji syntetycznej. Celem pracy było określenie skuteczności przeszczepu komórek tłuszczowych u pacjentów z jednostronnym niedowładem krtani po operacji tarczycy.

Materiał i metody: Zbadano 14 pacjentów z jednostronnym niedowładem krtani po operacji tarczycy. Wszystkim pacjentom zostały przeszczepione komórki tłuszczowe do mięśni głosowych. Operacje zostały przeprowadzone u 10 kobiet i 4 mężczyzn w wieku 39-62 lat. Czas zaburzeń ruchliwości krtani po operacji tarczycy wynosił od 7 miesięcy do 3 lat. Badania wykonano przed operacją i 5-7 lat po zabiegu. Patologia krtani przed operacją: jednostronne unieruchomienie fałdów głosowych (11 pacjentów), jednostronna fiksacja chrząstki nalewkowatej (2 pacjentów), kombinowane zaburzenia sprawności ruchowej krtani (1 pacjent). U wszystkich pacjentów przeprowadzono badanie videolaryngostroboskopowe i ocenę głosu, oznaczono maksymalny czas fonacji, oceniono chrypkę w głosie, i funkcje układu oddechowego, wykonano tomografię krtani.

Wyniki: Przez 5 lat po operacji u wszystkich pacjentów znacznie poprawiła się wydajność głosowa, ochronna i oddechowa funkcja krtani, co stwierdzono na podstawie subiektywnej samooceny i badania obiektywnego. Czas maksymalnej fonacji zwiększył się. Głos prawidłowy stwierdzono u 10 pacjentów, głos z lekką chrypką, ale znacznie lepszy niż przedoperacyjny u 4 pacjentów.

Wnioski: Przeszczep komórek tłuszczowych jest idealną, stosunkowo bezpieczną i łatwą do wykonania metodą rehabilitacji ambulatoryjnej stosowaną w celu funkcjonalnego odzyskiwania głosu u chorych $\mathrm{z}$ jednostronnym niedowładem krtani po operacji tarczycy. 


\section{Sesja III • Foniatria}

\section{Czynność gardła i krtani towarzysząca wyrażaniu emocji}

\section{Ewa Kazanecka ${ }^{1}$, Agnieszka Borowiec ${ }^{1,2}$, Agata Szkiełkowska ${ }^{1,3}$}

${ }^{1}$ Katedra Audiologii i Foniatrii, Uniwersytet Muzyczny Fryderyka Chopina, Warszawa

${ }^{2}$ Instytut Polonistyki Stosowanej, Uniwersytet Warszawski

${ }^{3}$ Światowe Centrum Stuchu, Instytut Fizjologii i Patologii Stuchu, Warszawa/Kajetany

Słowa kluczowe: czynności nadgłośniowe • emocje • nasofiberoskopia

Wyrażanie emocji związane jest $\mathrm{z}$ określonym modelem prozodycznym, czyli różni się zakresem wysokości i dynamiki głosu. Celem pracy było zbadanie czynności gardła i krtani towarzyszącej realizowaniu różnych emocji. Materiał stanowiło 16 osób (8 aktorów i 8 nieprofesjonalnych mówców), u których przeprowadzono badanie nasofiberoskopowe z oceną aktywności nadgłośniowej. Badani mieli za zadanie tworzyć ciągłą głoskę [i] na różnej wysokości i głośności, najpierw bez emocji na różnej wysokości i głośności, a następnie wyrażać na głosce [i] emocje: gniew, radość, strach, smutek, zdziwienie, obrzydzenie i pogardę. Do analizy wybrano $z$ każdego zadania obrazy video pochodzące $\mathrm{z}$ fazy rozpoczynania dźwięku i trwającej fonacji (łącznie 360 klatek). Porównywano stopień kompresji przestrzeni nadgłośniowych dla fonacji z wyrażaną emocją i bez emocji. Jednocześnie oceniano, jaka cecha głosu dominuje w poszczególnych emocjach. W obrazach fiberoskopowych gardła i krtani uzyskanych w przebiegu fonacji z wyrażaniem emocji stwierdzano większą kompresję niż na obrazach pochodzących $\mathrm{z}$ fonacji dźwięku wygodnego bez emocji.

Podczas realizowania obrzydzenia i gniewu stwierdzano największą kompresję gardła i przedsionka krtani. Wyrażanie obrzydzenia charakteryzuje głos niski i szorstki, natomiast gniew charakteryzuje głos o dużej głośności.

\section{Wpływ rehabilitacji funkcjonalnej na leczenie zaburzeń głosu u wokalistów}

\author{
Ewelina Sielska-Badurek, \\ Ewa Osuch-Wójcikiewicz
}

Klinika Otolaryngologii, Warszawski Uniwersytet Medyczny

Słowa kluczowe: wokalista • zburzenia głosu w śpiewie • dysodia • diagnostyka zaburzeń głosu w śpiewie • rehabilitacja czynnościowa • rehabilitacja funkcjonalna

Wprowadzenie: Wokaliści stanowią grupę zawodową o największym ryzyku wystąpienia zaburzeń głosu. Przejściowe zaburzenia głosu dotyczą każdego ze śpiewaków i mają najczęściej charakter czynnościowy. Do chwili obecnej nie powstały wytyczne dotyczące diagnostyki zaburzeń głosu w śpiewie, a większość badań jest dostosowana dla głosu w mowie. Cele badawcze: • Ocena efektów rehabilitacji funkcjonalnej śpiewaków. • Wyłonienie metod diagnostycznych, które są najbardziej czułe w wykrywaniu drobnych zmian w zakresie czynności traktu głosowego. - Stworzenie narzędzi do monitorowania efektów rehabilitacji funkcjonalnej. • Zaproponowanie standardów postępowania u wokalistów.

Materiał i metody: Materiał badawczy stanowiło 40 wokalistów, którzy zgłaszali się do Poradni Foniatrycznej WUM z zaburzeniami głosu w śpiewie, w latach 2010-2013. Metodyka w grupie badanej obejmowała wstępną ocenę narządu głosu, następnie rehabilitację funkcjonalną głosu oraz ocenę końcową. W grupie kontrolnej wykonano dwukrotnie pełną ocenę narządu głosu, w odstępie minimum 3 miesięcy.

Wnioski: • Rehabilitacja funkcjonalna stanowi skuteczne leczenie zaburzeń głosu u wokalistów. • Proponowany schemat diagnostyki zaburzeń głosu w śpiewie powinien obejmować: ocenę palpacyjną, ocenę odsłuchową jakości głosu w śpiewie, badanie akustyczne głosu (pole głosowe), ocenę videolaryngostroboskopową, ocenę aerodynamiczną (maksymalny czas fonacji) oraz samoocenę zaburzeń głosu w śpiewie dokonywaną za pomocą odpowiedniego kwestionariusza. - Ocena palpacyjna traktu głosowego, percepcyjna głosu oraz pole głosowe stanowią czułe narzędzia w wykrywaniu drobnych zmian w zakresie czynności narządu głosu. • W początkowym okresie rehabilitacji funkcjonalnej może dochodzić do skrócenia maksymalnego czasu fonacji. • Wyniki oceny palpacyjnej i percepcyjnej narządu głosu w mowie i śpiewie silnie ze sobą korelują. Mogą służyć jako zasada cross-check. 


\section{Powikłania pozaprzełykowe choroby refluksowej u dzieci}

\section{Sylwia Kędzierawska, Artur Niedzielski, Izabela Szlązak, Grażyna Niedzielska}

Katedra i Klinika Otolaryngologii Dziecięcej, Foniatrii i Audiologii, Lublin

Słowa kluczowe: zapalenie krtani • choroba refluksowa

Wprowadzenie: Refluks żołądkowo-przełykowy (GER) określa odpływ treści żołądkowej do przełyku, a objawy kliniczne związane z GER są rozpoznawane jako choroba refluksowa (GERD) która, stanowi poważny problem kliniczny. Powikłania z zakresu otolaryngologii są wynikiem pokonania górnego zwieracza przełyku przez treść żołądkową i podrażnienia błony śluzowej gardła i górnego odcinka drogi oddechowej. Coraz częściej GER jest rozpoznawany jako przyczyna zapalenia dróg oddechowych u dzieci. Celem pracy była ocena laryngologiczna, foniatryczna i audiologiczna pacjentów z rozpoznaną chorobą refluksową przełyku.

Materiał i metody: Materiał badań stanowiło 30 dzieci, pacjentów Kliniki Gastrologicznej UM w Lublinie. Wszyscy pacjenci mieli przeprowadzoną laryngoskopię lupową, endofiberoskopię nosogardła, ocenę percepcyjną głosu oraz analizę akustyczną. Celem wykluczania wysiękowego zapalenia ucha wykonano audiometrię impendancyjną $\mathrm{z}$ tympanometrią.

Wyniki: Najczęściej zgłaszanymi objawami chorobowymi były bóle brzucha, nudności, odbijanie oraz nieprzyjemny zapach z ust. Zmiany zapalne krtani były najczęściej spotykanym powikłaniem choroby refluksowej. Obrzęk nalewek oraz zmiany zapalno-obrzękowe fałdów głosowych były stwierdzane u $80 \%$ badanych. Analiza percepcyjna wykazała zmiany w zakresie cechy G, R i S. Największe odchylenia od normy w analizie akustycznej dotyczyły częstotliwości podstawowej oraz HNR.

Wnioski: Uważamy, że współpraca otolaryngologa-foniatry z gastrologiem jest istotna dla właściwego postępowania diagnostycznego i monitorowania leczenia.

\section{Ocena jakości głosu osób $\mathrm{z}$ refluksowymi zmianami w krtani i gardle dolnym przed i po leczeniu}

\section{Anna Domeracka-Kołodziej}

Katedra i Klinika Otolaryngologii WUM

Słowa kluczowe: refluks gardłowo krtaniowy • ocena subiektywna głosu • ocena obiektywna głosu

Wprowadzenie: Większość badań dotyczących działania treści refluksowej na krtań dokumentuje zmiany i efekty leczenia w obrazie laryngoskopowym. Mniej badań ocenia wpływ refluksu na jej czynność głosową. Celem pracy była ocena jakości głosu osób z refluksowymi zmianami w krtani i gardle dolnym przed leczeniem i po leczeniu.
Materiał i metody: Materiał stanowi 249 osób, u których w badaniu VLS rozpoznano cechy refluksowego zapalenia krtani i została potwierdzona przez gastrolo-gów GERD. Wśród nich było 166 kobiet, w wieku śr. 52,7 lat (18-84) oraz 83 mężczyzn w wieku śr. 49,7 lat (18-82). Wszystkim pacjentom wykonywano VLS, oceniano w skali RFS. Subiektywną ocenę głosu dokonywano w skali GRBAS a obiektywną przy użyciu analizatora KAY Elemetrics Model CSL 4300 z oprogramowaniem CSL 4305 i systemem MDVP.

Wyniki: W grupie badanej śr. wartość RFS min. 7 punktów. Po leczeniu w całej grupie zmiana była znamienna statystycznie. U pacjentów $\mathrm{z}$ refluksowymi zmianami w krtani i gardle dolnym $\mathrm{w}$ grupie kobiet w ocenie percepcyjnej głosu przeważa typ G2R1B0A0S1, a w grupie mężczyzn typ G2R2B0A0S1. W badaniach akustycznych charakterystyczną cechą jest III typ sonogramu według Remackle’a, chrypka II stopnia w skali Yanagihary, skrócenie czasu fonacji, w MDVP nieprawidłowe wartości wszystkich parametrów. Po leczeniu uzyskuje się znamienną statystycznie poprawę w zakresie: cechy G, R, B, S, typu sonogramu, cechy "niestacjonarność" i „dwugłos” w tonogramie, stopnia chrypki, niektórych parametrów MDVP (w grupie kobiet Fhi, RAP i PPQ, w grupie mężczyzn F0 i Flo).

Wnioski: W grupie badanej nie stwierdzono u żadnego pacjenta powrotu jakości głosu do przyjętej normy, pomimo ustąpienia dolegliwości, zwłaszcza gastrologicznych, które ustępują najszybciej.

\section{Rehabilitacja połykania po zabiegu rekonstrukcyjnym krtani - demonstracja przypadku}

\section{Anna Zebryk-Stopa ${ }^{1}$, Bożena Wiskirska-Woźnica ${ }^{2}$}

\footnotetext{
${ }^{1}$ Szpital Kliniczny im. H. Święcickiego Uniwersytetu Medycznego im. K. Marcinkowskiego w Poznaniu

${ }^{2}$ Katedra i Klinika Foniatrii i Audiologii, Uniwersytet Medyczny im. K. Marcinkowskiego w Poznaniu
}

Słowa kluczowe: laryngektomia rekonstrukcyjna • neurologopedia $\bullet$ rehabilitacja połykania

Postępowanie pooperacyjne w laryngektomii rekonstrukcyjnej, podobnie jak i w rozległych zabiegach onkologicznych w obrębie jamy ustnej i gardła wymaga standardowego postępowania medycznego, w które włączany jest na określonym etapie neurologopeda w przypadku pojawienia się trudności związanych z połykaniem i mową. Przedstawiony przypadek dotyczy 62-letniej pacjentki z guzem okolicy podgłośniowej, u której dokonano częściowej rekonstrukcji krtani płatem $\mathrm{z}$ fragmentem kostnym $\mathrm{z}$ uda. Po ekstubacji rozpoczęto naukę połykania równolegle z ćwiczeniami praksji oralnej ze względu na zniesienie prawidłowych czynności motorycznych w obrębie jamy ustnej. Uzyskano wyraźną poprawę w zakresie połykania i artykulacji z zaleceniem kontynuacji autorskiego zestawu ćwiczeń do czasu całkowitego powrotu funkcji. 


\section{Kompleksowa ocena narządu głosu u chorych dializowanych}

Waldemar Wojnowski, Alicja Grzegorzewska, Magdalena Kałos, Piotr Ŝwidziński, Bożena Wiskirska-Woźnica

\section{Rehabilitacja chorych $\mathrm{z}$ dysfonią porażenną krtani}

\section{Joanna Cieszyńska ${ }^{1}$, Grażyna Urbańska ${ }^{2}$, Jerzy Kuczkowski ${ }^{3}$, Tomasz Przewożny ${ }^{3}$, Piotr H. Skarżyński ${ }^{2}$}

\section{${ }^{1}$ Oddziat Otolaryngologiczny Szpitala im. Św. Wincentego a Paulo, Gdynia \\ ${ }^{2}$ Centrum Stuchu i Mowy Medincus \\ ${ }^{3}$ Klinika Otolaryngologii UCK Gdańskiego Uniwersytetu Medycznego}

Słowa kluczowe: porażenia krtani • leczenie

Wstęp: Dysfonia porażenna krtani (DPK) jest częstą niedomogą głosową powstającą po uszkodzeniu unerwienia krtani. Utrwalona DPK wywiera niekorzystny wpływ na funkcjonowanie oraz jakość życia chorego. Celem pracy było przedstawienie wyników rozpoznania oraz leczenia metodą wokalistyczno-fonetyczną głosu u chorych z DPK.

Material i metody: W okresie od 2003 do 2013 roku w trzech poradniach foniatrycznych na terenie Gdańska i Gdyni leczono 580 chorych (474 kobiety i 106 mężczyzn, w wieku od 28 do 74 lat) $\mathrm{z}$ dysfonią porażenną krtani (476 z jednostronną oraz 104 z obustronną). Wykonywano laryngoskopię pośrednią, badanie wideolaryngostroboskopowe, ocenę głosu w skali GRBAS, badanie akustyczne głosu, badanie czasu fonacji samogłoski przed leczeniem i po leczeniu. Oceniano tor oddechowy, czynność rezonatorów nasady, hiperfunkcję mięśni szyi oraz zdolność do kompensacji krtani w próbie Gutzmana. Czas rehabilitacji wahał się od 2 do 18 miesięcy. Prowadzono ćwiczenia zmieniające sposób oddychania ze statycznego na dynamiczny. Po uzyskaniu appogio, wykonywano ćwiczenia głosowe, których celem było zapobieganie zanikom mięśniowym i zwyrodnieniu w stawie pierścienno-nalewkowym oraz zmobilizowanie mechanizmów zastępczych warunkujących uzyskanie zwarcia fonacyjnego głośni. Po zakończeniu leczenia oceniano wyniki rehabilitacji w badaniu akustycznym oraz za pomocą skali percepcyjnej GRBAS.

Wyniki: W wyniku przeprowadzonej rehabilitacji uzyskano u chorych z DPK poprawę toru oddechowego oraz jakości głosu. Uzyskano poprawę głosu zarówno w ocenie percepcyjnej wg skali GRBAS, jak i w badaniu akustycznym.

Wnioski: Leczenie rehabilitacyjne tych chorych należy rozpoczynać jak najwcześniej, najlepiej bezpośrednio po wystąpieniu uszkodzenia nerwów krtaniowych i powinno być kontynuowane przez kilka miesięcy. Uzyskanie poprawy, jakości głosu zależy od zaangażowania chorego oraz zespołu foniatryczno-logopedycznego w czasie rehabilitacji.
Ocena wyników leczenia łagodnych zmian przerostowych fałdów głosowych metodą ostrzykiwania preparatem steroidowym (DepoMedrol)

\author{
Waldemar Wojnowski, Joanna Jackowska, \\ Magdalena Kałos, Bogna Małaczyńska, \\ Bożena Wiskirska-Woźnica
}

\section{Trudności diagnostyczne w rowku głośni}

\section{Beata Miaśkiewicz, Agata Szkiełkowska}

Światowe Centrum Słuchu, Instytut Fizjologii i Patologii Słuchu, Kajetany/Warszawa

Słowa kluczowe: rowek głośni • videolaryngostroboskopia - laryngoplastyka iniekcyjna • rehabilitacja głosu

Wstęp: Rowek głośni opisywany jest jako zagłębienie wzdłuż powierzchni wolnego brzegu fałdu głosowego. Ford wyróżnia trzy typy rowka: I - powierzchowny, dający nieznaczne zaburzenia głosu, IIa (vergeture) - charakteryzujący się atroficznym nabłonkiem i IIb (open cyst) wysłany pogrubiałym, hyperkeratotycznym nabłonkiem. Zaburzenia głosu o różnym stopniu nasilenia wynikają z niedomykalności fonacyjnej głośni oraz usztywnienia fałdów głosowych. Jego etiologia może być wrodzona lub nabyta. Celem pracy była charakterystyka patologii, przedstawienie trudności diagnostycznych oraz prezentacja grupy pacjentów leczonych z powodu rowka głośni w IFPS.

Materiał i metody: Materiał pracy stanowiła grupa 49 pacjentów z rowkiem głośni. W 29 przypadkach rozpoznano typ I rowka głośni, u 18 typ IIa, a u pozostałych 2 osób typ IIb. U 20 pacjentów stwierdzono obustronny rowek głośni, a u 29 jednostronny. U wszystkich pacjentów, przed leczeniem i po jego zakończeniu, przeprowadzono badanie videolaryngostroboskopowe (VLS), percepcyjną ocenę głosu (GRBAS) oraz obiektywne badanie akustyczne głosu (MDVP). Pacjenci z rowkiem głośni typu I (29 osób) nie wymagali leczenia. U 3 badanych osób zastosowano leczenie zachowawcze (rehabilitacja głosu), a u 17 leczenie operacyjne, które u 9 obejmowało laryngoplastykę iniekcyjną z zastosowaniem kwasu hialuronowego, u 2 wypreparowanie rowka głośni za pomocą promienia lasera $\mathrm{CO}_{2}$, a w 6 przypadkach wypreparowanie rowka głośni uzupełnione iniekcją kwasu hialuronowego. U wszystkich pacjentów leczonych operacyjnie przeprowadzono przedi pooperacyjną rehabilitację głosu.

Wyniki: Postawienie właściwej diagnozy jest trudne, nawet przy zastosowaniu badania VLS i ostateczne potwierdzenie/rozpoznanie rowka głośni często odbywa się podczas zabiegu fonochirurgicznego w znieczuleniu ogólnym. Rozpoznanie rowka głośni typu I było postawione na podstawie badania stroboskopowego jako bardzo dyskretne wpuklenie błony śluzowej wolnego brzegu, nie zaburzające przesunięcia brzeżnego i zwarcia fonacyjnego. U 3 pacjentów leczonych zachowawczo rowek typu IIa został stwierdzony w badaniu VLS. Spośród 17 chorych leczonych chirurgicznie, u 11 rozpoznanie rowka głośni typu 
IIa postawiono na podstawie przedoperacyjnego badania VLS i potwierdzono śródoperacyjnie; u pozostałych 6 badanych wstępnie rozpoznano bliznę, atrofię lub cystę epidermoidalną fałdu głosowego a diagnozę rowka głośni postawiono śródoperacyjnie (3 osoby - typ IIa, 2 osoby - typ IIb). W badaniu VLS u pacjentów $\mathrm{z}$ rowkiem typu IIa i IIb stwierdzono owalną szparę fonacyjną $\mathrm{z}$ wklęśniętym wolnym brzegiem fałdu głosowego oraz osłabienie lub brak przesunięcia brzeżnego po stronie patologii. W zależności od stopnia niedomykalności głośni głos u pacjentów był w różnym stopniu ochrypnięty, zazwyczaj podwyższony, chuchający, napięty. Zaburzenia głosu w skali percepcyjnej GRBAS korelowały $\mathrm{z}$ wartościami parametrów ocenianych w obiektywnym badaniu akustycznym głosu (MDVP).

Wnioski: 1. Rowek głośni jest patologią trudną do rozpoznania, nawet w badaniu videolaryngostroboskopowym. Czasem dopiero ocena śródoperacyjna pozwala postawić ostateczne rozpoznanie. 2 . W diagnostyce różnicowej należy wziąć pod uwagę bliznę lub zmiany atroficzne fałdu głosowego (np. presbyfonia). 3. Leczenie operacyjne powinno być rozważone w przypadkach rowka głośni przebiegającego z zaburzeniami głosu (typ IIa i IIb).

\section{Rola czynników prozodycznych w wyrażaniu emocji}

\author{
Agnieszka Borowiec ${ }^{1,2}$, Ewa Kazanecka1, \\ Agata Szkiełkowska ${ }^{1,3}$ \\ ${ }^{1}$ Katedra Audiologii i Foniatrii, Uniwersytet Muzyczny \\ Fryderyka Chopina, Warszawa \\ ${ }^{2}$ Instytut Polonistyki Stosowanej, Uniwersytet Warszawski \\ ${ }^{3}$ Światowe Centrum Stuchu, Instytut Fizjologii i Patologii \\ Stuchu, Warszawa/Kajetany
}

Słowa kluczowe: prozodia • emocje • jakość głosu

Umiejętność wyrażania emocji jest podstawą kształcenia aktorskiego. Jednym $\mathrm{z}$ istotnych elementów przekazu emocji są zmiany głosu. Celem pracy było zbadanie, czy istnieją wzorce głosowe charakteryzujące konkretne emocje. Grupę badawczą stanowiło 15 osób (8 aktorów i 7 nieprofesjonalnych mówców), 5 mężczyzn i 10 kobiet. Każdy badany na jednym, dwusylabowym słowie wyrażał następujące emocje: gniew, radość, smutek, obrzydzenie, pogardę, strach, zdziwienie. Nagrane wypowiedzi wstępnie oceniano odsłuchowo pod kątem czytelności oraz wyznaczenia linii melodycznej, głośności i czasu trwania. Następnie weryfikowano te cechy na podstawie analizy akustycznej za pomocą programu Audacity, wyznaczając dla każdej sylaby F0, poziom natężenia i długość realizacji. Sporządzono 105 przebiegów prozodycznych, które zestawiono z czytelnością emocji. W wyniku analizy zdefiniowano cechy najczęściej pojawiające się w danym typie emocji, co pozwoliło na wyznaczenie wzorców prozodycznych. Odstępstwa od nich osłabiają czytelność bądź teatralizują wypowiedź. Poszczególne elementy prozodii powinny zatem stanowić zespół zrównoważonych cech.

\section{Leczenie chirurgiczne obustronnego porażenia fałdów głosowych - doświadczenia własne oraz przegląd literatury}

\author{
Wojciech Kukwa, Jan Ratajczak, Małgorzata \\ Tomaszewska
}

Klinika Otorynolaryngologii Wydziału Lekarsko-Dentystycznego WUM $w$ Warszawie

Słowa kluczowe: porażenie fałdów głosowych • arytenoidektomia

Wprowadzenie: Celem pracy jest przedstawienie możliwości leczenia chirurgicznego zwężenia szpary głośni, powstałego na skutek obustronnego porażenia fałdów głosowych różnego pochodzenia. Porównanie metod klasycznych (arytenoidectomii całkowitej i laterofiksacji metodą Lichtenbergera) do laserowej chordektomii techniką Kashima. Jak uniknąć tracheostomii? Kiedy zastosować daną procedurę? Przybliżenie technik operacyjnych oraz postępowanie po zabiegu.

Materiał i metody: W latach 2010-2013 wykonano 35 zabiegów poszerzenia głośni metodą arytenoidektomii podśluzówkowej z laterofiksacją. Zabieg wykonywano na podstawie oceny foniatrycznej. W 8 przypadkach stosowano 24-godzinną intubację pozabiegową.

Wyniki: We wszystkich przypadkach uzyskano poszerzenie głośni i poprawę wydolności oddechowej pacjenta. U żadnego pacjenta nie wystąpił problem z połykaniem. W żadnym przypadku nie wykonano tracheostomii. U większości pacjentów po usunięciu szwu zewnętrznego i krótkiej rehabilitacji foniatrycznej głos wracał do stanu sprzed operacji.

Wnioski: Klasyczna arytenoidektomia podśluzówkowa pozostaje bardzo skuteczną metodą leczenia w przypadku obustronnego porażenia fałdów głosowych z wąską szparą głośni. Brak jakichkolwiek termicznych uszkodzeń śluzówki powoduje całkowite wyeliminowanie ryzyka patologicznego bliznowacenia w okresie pooperacyjnym.

\section{Aspekty foniatryczne chorób górnych dróg oddechowych u dzieci}

\section{Grażyna Niedzielska}

Katedra i Klinika Otolaryngologii Dziecięcej, Foniatrii i Audiologii w Lublinie

Zaburzenia rezonansu nosowego są częsta patologią wieku dziecięcego. Istnieją doniesienia o wpływie rezonansu nosowego na jakość głosu. Zarówno nosowanie zamknięte, jak i nosowanie otwarte ma negatywny wpływ na jakość głosu i mowy. Głównymi cechami mowy u pacjentów z niewydolnością podniebienno-gardłową jest opóźniony rozwój mowy, zmiana rezonansu, wadliwa artykulacja oraz hiperfunkcyjny sposób tworzenia głosu. Najczęstszym powodem hospitalizacji w oddziałach otolaryngologii dziecięcej są choroby migdałków. Wpływowi leczenia operacyjnego na jakość głosu poświęcono niewiele prac w literaturze. 
W większości dotyczą pomiarów subiektywnych. Badania przeprowadzane w ostatnich latach w oparciu o analizę akustyczną głosu wykazały zmiany badanych parametrów w wyniku przeprowadzonego leczenia. Podobne wyniki uzyskano u pacjentów leczonych z powodu skrzywień przegrody nosa. Powiększeniu migdałków u dzieci często towarzyszą bezdechy senne. Okazuje się, że również w tej grupie pacjentów stwierdza się zmiany akustyczne głosu po operacji związanej z chrapaniem. Przeprowadzane badania jednoznacznie wskazują na korzystny wpływ adenotonsillotomii na jakość mowy oraz stopień zwarcia podniebienno-gardłowego. U dzieci z powiększonymi migdałkami podniebiennymi podniebienie miękkie może okazać się zbyt krótkie, aby osiągnąć tylną ścianę gardła, co jest warunkiem niezbędnym do wytwarzania głosek ustnych. Zatem zaburzenia rezonansu spowodowane patologią w obrębie pierścienia Waldeyera wpływają nie tylko na głos, lecz także na jakość mowy.

\section{Sesja VII • Szumy uszne, zawroty głowy}

\section{Ocena częstości występowania szumów usznych w populacji 7- i 12-latków mieszkających w Warszawie}

\section{Danuta Raj-Koziak, Anna Piotrowska, Krzysztof Tarczyński, Krzysztof Kochanek, Henryk Skarżyński}

Światowe Centrum Słuchu, Instytut Fizjologii i Patologii Słuchu, Warszawa/Kajetany

Słowa kluczowe: szumy uszne • dzieci • niedosłuch

Wprowadzenie: Problem szumów usznych został bardzo dobrze rozpoznany wśród osób dorosłych. W ciągu ostatnich trzech dekad obserwuje się wzrost liczby publikacji na temat częstości występowania szumów usznych wśród dzieci, ale prezentowane wyniki różnią się między sobą w szerokim zakresie, co nie pozwala zająć jednoznacznego stanowiska. Celem pracy była ocena częstości występowania szumów usznych wśród dzieci w wieku 7 i 12 lat mieszkających w Warszawie.

Materiał i metody: Materiał pracy stanowiło ponad 15000 odpowiedzi ankietowych na temat występowania szumów uzyskanych od dzieci oraz od ich rodziców. U każdego dziecka wykonano badanie audiometryczne słuchu dla częstotliwości 0,$5 ; 1 ; 2 ; 4$ i $8 \mathrm{kHz}$.

Wyniki: Częstość występowania szumów usznych w badanej populacji stwierdzono na poziomie $35,1 \%$. Wśród dzieci z prawidłowym wynikiem przesiewowego badania słuchu występowanie szumów usznych potwierdziło 34,3\% badanych. Częstość występowania szumów usznych wśród dzieci $\mathrm{z}$ niedosłuchem jednostronnym wyniosła $40,1 \%$ oraz $42,2 \%$ $\mathrm{u}$ badanych $\mathrm{z}$ niedosłuchem obustronnym. Czynnik ryzyka wystąpienia szumów usznych był wyższy w grupie dzieci $\mathrm{z}$ niedosłuchem $\mathrm{w}$ porównaniu $\mathrm{z}$ grupą dzieci prawidłowo słyszących.

Wnioski: Szumy uszne są częstym problemem wśród dzieci, lecz nie zawsze istotnym klinicznie.

\section{Ocena wyników badania videonystagmograficznego i elektronystagmograficznego u dzieci z zawrotami głowy}

Renata Pepaś ${ }^{1}$, Małgorzata Śmiechura ${ }^{1}$, Małgorzata Strużycka ${ }^{1}$, Wiesław Konopka ${ }^{1,2}$

\footnotetext{
${ }^{1}$ Klinika Otolaryngologii, ICZMP, Łódź

${ }^{2}$ Uniwersytet Medyczny $w$ Łodzi
}

Słowa kluczowe: zawroty głowy $• \mathrm{VNG} \cdot \mathrm{ENG} \bullet$ dzieci

Wprowadzenie: U dorosłych częstość występowania zawrotów głowy określa się na 20 do 30\% ogólnej populacji, a u dzieci na $8-18 \%$. Najczęściej już w 4 roku życia dziecko osiąga wystarczającą dojrzałość układu nerwowego, aby $\mathrm{w}$ diagnostyce układu przedsionkowego używać wszystkich testów stosowanych u osób dorosłych. Przyjmuje się, że pełne badanie ENG i VNG wraz z próbami kalorycznymi może być wykonane już w 5 roku życia. Celem pracy była ocena wyników badania wideonystagmograficznego i elektronystagmograficznego u dzieci z zawrotami głowy i zaburzeniami równowagi.

Materiał i metody: Badaniem objęto grupę 30 chorych (14 dziewczynek i 16 chłopców) w wieku od 5 do 17 lat (średnio 14 $\pm 3,4$ lat) diagnozowanych $z$ powodu długotrwałych zawrotów głowy i zaburzeń równowagi. U wszystkich badanych wykonano badanie otolaryngologiczne oraz otoneurologiczne, diagnostykę audiologiczną, a także badanie elektronystagmograficzne (12 badanych) lub wideonystagmograficzne (18 osób) z oceną oczopląsu samoistnego, próbami położeniowymi, okoruchowymi i wodnymi próbami kalorycznymi, z oceną niedowładu kanałowego i przewagi kierunkowej.

Wyniki: Skompensowane uszkodzenie obwodowej części układu równowagi rozpoznano u 8 pacjentów, natomiast uszkodzenie typu ośrodkowego u 21 badanych, a u 1 osoby zaobserwowano całkowity brak pobudliwości błędników towarzyszący obustronnej głuchocie wrodzonej. U 4 dzieci nie udało się ukończyć badania nystagmograficznego (bardzo nasilone objawy wegetatywne, tuby wentylacyjne - brak prób kalorycznych).

Wnioski: Większość zawrotów głowy występujących wśród dzieci nie jest związana $z$ uszkodzeniem obwodowej części układu równowagi. Badanie elekronystagmograficzne i wideostygmograficzne jest niezwykle cenne w ocenie lokalizacji uszkodzenia układu równowagi i razem $\mathrm{z}$ badaniem podmiotowym, przedmiotowym, badaniami dodatkowymi stanowi nierozłączny element diagnostyki otoneurologicznej. 


\section{Ocena tympanometrii wieloczęstotliwościowej $\mathrm{w}$ diagnostyce ucha środkowego u małych dzieci}

\author{
Aneta Sączek ${ }^{1}$, Edyta Piłka ${ }^{2}$, \\ Krzysztof Kochanek ${ }^{1,2}$, Artur Niedzielski ${ }^{3}$, \\ Henryk Skarżyński ${ }^{2}$
}

\section{${ }^{1}$ Zakład Logopedii i Językoznawstwa Stosowanego, Wydział Humanistyczny, UMCS, Lublin \\ ${ }^{2}$ Światowe Centrum Słuchu, Instytut, Fizjologii i Patologii Stuchu, Warszawa/Kajetany \\ ${ }^{3}$ Pracownia Otoneurologii III Katedry Pediatrii Uniwersytetu Medycznego $w$ Lublinie}

Słowa kluczowe: tympanometria wieloczęstotliowściowa $\bullet$ MFT

\begin{abstract}
Wprowadzenie: Audiometria impedancyjna należy do rutynowych badań wykonywanych w diagnostyce zaburzeń słuchu u małych dzieci. Standardowo w pomiarach tympanometrycznych stosuje się ton próbny o częstotliwości 220 lub $226 \mathrm{~Hz}$. Jednakże coraz częściej istotne znaczenie diagnostyczne przypisuje się tympanometrii wieloczęstotliwościowej (ang. MFT - Multifrequency Tympanometry), szczególnie przy użyciu tonu próbnego o częstotliwości $1000 \mathrm{~Hz}$, która umożliwia ocenę poszczególnych elementów składowych admitancji ucha. Celem niniejszej pracy jest ocena wiarygodności MFT w diagnostyce ucha środkowego u małych dzieci oraz porównanie parametrów pomiarowych uzyskiwanych $\mathrm{z}$ wykorzystaniem dwu częstotliwości pomiarowych: $226 \mathrm{~Hz}$ oraz $1000 \mathrm{~Hz}$.
\end{abstract}

Materiał i metody: Materiał pracy obejmował 58 noworodków, przebywających w Klinice Patologii Noworodków Dziecięcego Szpitala Klinicznego w Lublinie. Każde z dzieci zostało poddane badaniu podatności ucha środkowego z wykorzystaniem dwu częstotliwości pomiarowych: $226 \mathrm{~Hz}$ oraz $1000 \mathrm{~Hz}$. Uzyskane wyniki pozwoliły na porównanie parametrów otrzymanych przy użyciu dwu częstotliwości pomiarowych oraz na ocenę efektywności stosowania częstotliwości $1000 \mathrm{~Hz} \mathrm{w}$ diagnostyce ucha środkowego u małych dzieci.

Wyniki: Rezultaty przeprowadzonych badań wskazują, iż wykresy tympanometryczne otrzymywane dla tych samych uszu, z wykorzystaniem różnych częstotliwości, różnią się znacznie od siebie. Ponadto $\mathrm{w}$ przypadku częstotliwości $1000 \mathrm{~Hz}$ odnotowuje się większy odsetek krzywych typu B.

Wnioski: Na podstawie uzyskanych wyników stwierdza się, że krzywe tympanometryczne dla częstotliwości pomiarowych $226 \mathrm{~Hz}$ oraz $1000 \mathrm{~Hz}$ mają zróżnicowane kształty, przy czym częstotliwość $1000 \mathrm{~Hz}$ w grupie noworodków ukazuje większy odsetek patologii ucha środkowego. Istnieje zatem potrzeba prowadzenia dalszych badań, a co za tym idzie - wprowadzenia standardów diagnozowania schorzeń ucha środkowego u małych dzieci, w celu weryfikacji użyteczności MFT jako metody diagnostycznej o wysokiej czułości.

\section{Wpływ szumów usznych na funkcje poznawcze $z$ użyciem testu uwagi}

\author{
Barbara Maciejewska, \\ Bożena Wiskirska-Woźnica, \\ Katarzyna Studzińska, Agnieszka Pilarska
}

Katedra i Klinika Foniatrii i Audiologii, UM Poznań

\begin{abstract}
Słowa kluczowe: szumy uszne • funkcje poznawcze • uwaga
\end{abstract}

Wprowadzenie: Funkcje poznawcze są odpowiedzialne za odbieranie informacji ze świata zewnętrznego, a ich sprawność wyznacza próg możliwości w realizacji wszelkiego rodzaju celów życiowych. Uwaga pełni funkcję selekcji informacji docierających do mózgu za pośrednictwem narządów zmysłu. Ograniczenia wynikające ze struktury i sposobu działania systemu poznawczego wymuszają kontrolę procesów odbioru i przetwarzania bodźców, tak by nie doszło do niebezpiecznych skutków przeładowania. Nowoczesna medycyna stawia sobie nowe cele, w których nie ogranicza się jedynie do redukcji objawów klinicznych określonych w poszczególnych jednostkach chorobowych, ale dąży również do podnoszenia jakości życia. Ta ostatnia zmienna staje się dobrem najwyższym, szczególnie wśród pacjentów chorych np. na szumy uszne. W proces percepcji szumu zaangażowany jest nie tylko układ słuchowy, lecz także układ limbiczny (odpowiedzialny za emocje), autonomiczny układ nerwowy (odpowiedzialny za reakcje obronne) i obszary kory czołowej (odpowiedzialne za nadawanie znaczenia). Deficyty uwagi coraz częściej stają się główną skargą pacjentów i zmuszają ich do poszukiwań oddziaływań medycznych. Celem pracy jest ocena wpływu szumów usznych na sprawność i wydajność uwagi.

Materiał i metody: Badaniem objęto 30 pacjentów z szumem usznym jako dolegliwością główną lub współistniejącą. Wykonano rozszerzoną diagnostykę audiologiczną (badanie psychofizyczne i obiektywne słuchu) z uwzględnieniem audiometrii tonalnej, mowy, impedancyjnej, otoemisji akustycznej, potencjałów wywołanych pnia mózgu oraz ocene charakteru szumu usznego, test uwagi, wskaźnik niepełnosprawności (tinnitus handicap Index).

Wnioski: Odnotowano istotne pogorszenie wszystkich parametrów uwagi u pacjentów z szumem usznym; było ono (paradoksalnie) największe u pacjentów, u których szum uszny nie współwystępował $\mathrm{z}$ innymi dolegliwościami. Może to sugerować inny patomechanizm szumów w tej grupie pacjentów lub/i słabsze mechanizmy kompensacyjne. 


\section{Weryfikacja audiologiczna objawów otologicznych w przebiegu zaburzeń układu ruchowego narządu żucia}

\section{Barbara Maciejewska', Zofia Maciejewska-Szaniec², Bożena Wiskirska-Woźnica ${ }^{1}$, Paweł Piotrowski}

${ }^{1}$ Katedra i Klinika Foniatrii i Audiologii, UM Poznań

${ }^{2}$ Klinika Rehabilitacji Narządu Żucia, UM Poznań

Słowa kluczowe: objawy otologiczne • układ stomatognatyczny

Wprowadzenie: Objawy ze strony narządu słuchu (szumy uszne, otalgia, nadwrażliwość na dźwięki, uczucie pełności, pogorszenie słuchu) pojawiają się nie tylko w przebiegu chorób laryngologiczno-audiologicznych, ale towarzyszą patologicznym stanom uzębienia: utrudnione wyrzynanie zębów, zapalenie miazgi, dysfunkcja układu stomatognatycznego (US). Objawy kliniczne w obrazie zaburzeń czynnościowych US są zróżnicowane w lokalizacji i stopniu nasilenia. Celem pracy była audiologiczna weryfikacja objawów otologicznych (OO) pacjentów z dysfunkcją US, i ustalenie czy subiektywnie zgłaszane objawy otologiczne znajdują obiektywne potwierdzenie w badaniach słuchu.

Materiał i metody: przebadano stomatologicznie 183 pacjentów z Kliniki Rehabilitacji Narządu Żucia UM z dolegliwościami ze strony US (badanie zewnątrzustne, wewnątrzustne oraz czynnościowe, objawy akustyczne podczas ruchów żuchwy, jej tor przywodzenia, odwodzenia, tkliwość palpacyjną mięśni skrzydłowych bocznych i dna jamy ustnej). 58 pacjentów (31,69\%), którzy zgłaszali OO, skonsultowano w Katedrze i Klinice Foniatrii i Audiologii celem weryfikacji ich pochodzenia. Do oceny narządu słuchu zastosowano metody psychofizyczne i obiektywne słuchu.

Wyniki: uszkodzenie słuchu wykazano u 27 z 58 osób (46,55\%). Zdiagnozowano: niedosłuch przewodzeniowy $(37,04 \%)$, odbiorczy $(55,56 \%)$, mieszany $(n=41 \%)$. Przyczyny: ootoskleroza (3,70\%), tympanoskleroza (7,41\%), zaburzenia drożności trąbek słuchowych $(25,93 \%)$ współwystępujące ze zmianami starczymi $(7,41 \%)$, presbyacusis $(40,74 \%)$, uraz akustyczny $(11,11 \%)$. U 31 osób z OO w ankiecie wykluczono uszkodzenie narządu słuchu (UP=12,52 $\mathrm{dBHL}, \mathrm{UL}=10,70 \mathrm{dBHL}$ ). W grupie pacjentów $\mathrm{z}$ dysfunkcjami URNŻ różnicującym objawem jest niedosłuch, zdecydowanie częściej związany z chorobą słuchu p=0,0364.

Wnioski: 1. Pacjenci, u których OO w przebiegu zaburzeń US występują bez wykładników procesu patologicznego toczącego się w narządzie słuchu, są podejrzani o występowanie OO uwarunkowanych dysfunkcją US. 2. Objawem różnicującym pochodzenie OO jest niedosłuch.

\section{Wartość diagnostyczna testu VHIT w uszkodzeniach kanałów półkolistych u chorych z zawrotami głowy}

\author{
Piotr Pietkiewicz, Jarosław Miłoński, \\ Marzena Bielińska, Joanna Urbaniak, \\ Anna Jałocha-Kaczka, Jurek Olszewski
}

\section{Klinika Otolaryngologii i Onkologii Laryngologicznej, UM} $w$ Łodzi

Słowa kluczowe: Videonystagmography Head Impulse Test (VHIT) • uszkodzenie kanałów półkolistych • zawroty głowy

Wprowadzenie: Celem pracy była ocena wartości diagnostycznej testu VHIT w uszkodzeniach kanałów półkolistych u chorych z zawrotami głowy i zaburzeniami równowagi.

Materiał i metody: Badania wykonano u 135 pacjentów (86 kobiet i 49 mężczyzn) w wieku 22-79 lat, których podzielono na dwie grupy: I (badana) - 73 pacjentów z zawrotami głowy typu obwodowego, ośrodkowego lub mieszanego, II (kontrolna) - 62 pacjentów bez zawrotów głowy (zdrowi). Czynność kanału określana była na podstawie tzw. wzmocnienia w procentach (GAIN), wyrażonego wzorem: $\mathrm{DG} / \mathrm{RH} \times 100 \%$, gdzie DG oznacza przesunięcie wzroku, a RH określa przesunięcie głowy. Prawidłowa wartość GAIN waha się w granicach 1-40\%.

Wyniki: W badanym materiale uszkodzenie kanałów połkolistych w grupie badanej stwierdzono u 37 (50,69\%) pacjentów, w tym 1 kanał u 24 (32,87\%) chorych i u 13 $(17,80 \%)$ chorych jednocześnie 2 lub 3 kanały. Uszkodzenie kanału półkolistego przedniego opisano 13-krotnie, bocznego 9-krotnie i tylnego 31-krotnie.

Wnioski: W badanej grupie uszkodzenie kanałów półkolistych w teście VHIT stwierdzono u chorych w 50,68\% przypadków z zawrotami typu obwodowego lub mieszanego skompensowanego lub nieskompensowanego, podczas gdy w teście kalorycznym dysfunkcję narządu przedsionkowego opisano w 58,49\% przypadków. 


\section{Porównanie stymulacji kalorycznej wodnej i powietrznej w badaniu wideonystagmograficznym}

\section{Anna Jałocha-Kaczka, Piotr Pietkiewicz, Joanna Michalska, Jurek Olszewski}

Klinika Otolaryngologii i Onkologii Laryngologicznej, UM $w$ Łodzi

Słowa kluczowe: powietrzna i wodna stymulacja kaloryczna $\bullet$ narządy przedsionkowe $\bullet$ VNG

Wprowadzenie: Celem pracy była cena czułości stymulacji kalorycznej narządów przedsionkowych za pomocą próby wodnej i powietrznej w badaniu wideonystagmograficznym.

Material i metody: Badania przeprowadzono u 18 kobiet w wieku 21-63 lat i 11 mężczyzn w wieku 21-74 hospitalizowanych w Klinice Otolaryngologii i Onkologii Laryngologicznej UM w Łodzi z rożnych przyczyn laryngologicznych, ale bez zawrotów głowy i zaburzeń równowagi. Kryteriami włączenia osób do badania były: szczegółowy wywiad na podstawie ankiety obejmującej: wywiad zawrotowy, choroby przebyte, choroby przewlekłe, przyjmowane leki oraz badanie przedmiotowe otoneurologiczne. Test kaloryczny wykonano przy użyciu kalorymetru powietrznego lub wodnego firmy HOMOTH, używając temperatury powietrza $300^{\circ} \mathrm{C}$ oraz $440^{\circ} \mathrm{C}$ (przerwa miedzy nimi $12 \mathrm{~min}$ ), podawanych przez $40 \mathrm{~s}$ do przewodów słuchowych zewnętrznych po wcześniejszym wykluczeniu procesów chorobowych przewodu słuchowego zewnętrznego i ucha środkowego. Przerwa między stymulacją powietrzną a wodną wynosiła 2 godziny. Zapisów dokonano przy użyciu komputerowych systemów analizy wideonystagmograficznej, pozwalających na obliczenie osłabienia pobudliwości i przewagi kierunkowej względnej i bezwzględnej, maksymalnej prędkości fazy wolnej oczopląsu oraz jego częstotliwości.

Wyniki: U wszystkich pacjentów oceniane parametry w badaniu VNG, zarówno podczas stymulacji powietrznej, jak i wodnej narządów przedsionkowych mieściły się $\mathrm{w}$ granicach normy, ale różniły się znacznie między sobą. Stwierdzono znamienną statystycznie średnią różnicę w badaniu deficytu przedsionkowego, ale tylko w przypadku ucha lewego ( $w \%)-p=0,007$, bezwzględnej przewagi kierunkowej ( $\mathrm{w}$ o/s) $-\mathrm{p}<0,001$, względnej przewagi kierunkowej ( $\mathrm{w} \mathrm{o} / \mathrm{s})-\mathrm{p}<0,001)$, pobudliwości ( $\mathrm{w} \mathrm{o} / \mathrm{s}$ ) - $\mathrm{p}<0,001$, prędkości ( $\mathrm{w}$ o/s) - $\mathrm{p}<0,001$, częstotliwości (w Hz) - p $<0,001$, zarówno w uchu prawym, jak i lewym dla obu prób.

Wnioski: Próba wodna stymulacji kalorycznej narządów przedsionkowych jest bardziej czuła niż powietrzna, na co wskazują otrzymane parametry w rejestracji VNG.

\section{Stosowanie doustnych środków antykoncepcyjnych a występowanie zawrotów głowy}

\section{Joanna Urbaniak, Hanna Zielińska-Bliźniewska, Jarosław Miłoński, Piotr Pietkiewicz, Jurek Olszewski}

Klinika Otolaryngologii i Onkologii Laryngologicznej, UM $w$ Łodzi

Słowa kluczowe: doustne środki antykoncepcyjne • parametry układu hemostazy • zawroty głowy

Wprowadzenie: Celem pracy była ocena wpływu działania doustnych środków antykoncepcyjnych na wybrane parametry układu hemostazy u młodych kobiet $\mathrm{z}$ nagłym zaburzeniem czynności narządu słuchu i/lub układu równowagi.

Materiał i metody: Badaniami objęto 105 młodych kobiet hospitalizowanych w Klinice Otolaryngologii i Onkologii Laryngologicznej Uniwersyteckiego Szpitala Klinicznego im. WAM w Łodzi, które podzielono na 2 grupy: I - 52 kobiety z zaburzeniem czynności słuchu i/lub układu równowagi, stosujących hormonalne leki antykoncepcyjne od co najmniej 2 miesięcy, w wieku od 20 do 49 lat, II - 53 kobiety bez zaburzeń czynności słuchu i/lub układu równowagi, stosujących hormonalne leki antykoncepcyjne od co najmniej 2 miesięcy, w wieku od 18 do 40 lat. U pacjentek włączonych do badania przeprowadzono: wywiad, badanie przedmiotowe laryngologiczne i otoneurologiczne, badanie wideonystagmograficzne i audiometryczne, tomografię komputerową i badanie przepływu krwi metodą dopplerowską w tętnicach kręgowych i podstawnej. U wszystkich chorych wykonano badanie parametrów układu hemostazy - poziom fibrynogenu, D-dimeru, wskaźnika APTT i PT i stężenia estradiolu i progesteronu w surowicy krwi.

Wyniki: W badaniach własnych stwierdzono, że stężenie estradiolu w surowicy krwi, po uwzglednieniu fazy cyklu miesięcznego w grupie badanej było nieprawidłowe u 41,2\% kobiet i różnice w jego stężeniu były istotne statystycznie $w$ grupie badanej i kontrolnej $(p=0,005)$. Analiza stężenia progesteronu w surowicy krwi, po uwzględnieniu fazy cyklu miesięcznego w grupie wykazała, że jego wartość była nieprawidłowa u 51,0\% kobiet w grupie badanej i u 47,1\% pacjentek w grupie kontrolnej. Analizowane parametry biochemiczne związane $\mathrm{z}$ krzepnięciem krwi takie jak: stężenie D-dimerów, fibrynogen i czas protrombinowy były nieprawidłowe $\mathrm{w}$ grupie badanej, odpowiednio w $19,2 \%, 19,2 \%$ i $86,5 \%$ przypadków, natomiast w grupie kontrolnej, odpowiednio w $18,95 \%, 26,4 \%$ i 94,3\% przypadków.

Wnioski: Stwierdzono statystyczną zależność w różnicy stężenia estradiolu $\mathrm{w}$ fazie folikularnej i szczycie owulacyjnym oraz progesteronu w szczycie owulacyjnym i w fazie lutealnej między grupą badaną a kontrolną. 


\section{Organizacja tonotopowa pierwotnej kory słuchowej u pacjentów $\mathrm{z}$ przewlekłym obustronnym szumem usznym: badania fMRI}

\author{
Tomasz Wolak, Monika Lewandowska, \\ Iwona Niedziałek, Katarzyna Cieśla, \\ Agnieszka Pluta, Mateusz Rusiniak, \\ Henryk Skarżyński
}

Światowe Centrum Sluchu, Instytut Fizjologii i Patologii Stuchu, Warszawa/Kajetany

\section{Słowa kluczowe: szum uszny • tonotopia $\bullet$ fMRI • kora słuchowa}

Wprowadzenie: Zjawisko szumu usznego polega na percepcji dźwięków przy braku zewnętrznego źródła tych dźwięków. Ostatnie badania przeprowadzone na zwierzętach (Engineer i wsp. 2011) sugerują, że szumom usznym towarzyszy zmiana organizacji tonotopowej w korze słuchowej, jakkolwiek badania na ludziach dają niespójne rezultaty. W pracy Langersa i współpracowników (2012) nie stwierdzono nieprawidłowości w organizacji tonotopowej u pacjentów z szumem usznym. Ponieważ w dalszym ciągu nie ma pewności co do zmian w korze słuchowej spowodowanych szumem usznym, w niniejszej pracy przedstawiamy wyniki badań na grupie osób dorosłych z chronicznym (powyżej 6 miesięcy) obustronnym szumem usznym.
Materiał i metody: Przebadano 16 pacjentów (w wieku $43 \pm 5$ lat) oraz 14 osób z grupy kontrolnej (46 \pm 3 lat) ze słuchem w granicach normy za pomocą techniki funkcjonalnego rezonansu magnetycznego (fMRI). Zadaniem osoby badanej było słuchanie dwu- i trzytonowych dźwięków o częstotliwości środkowej 400, 800,1600,3200, $6400 \mathrm{~Hz}$ oraz częstotliwości zbliżonej do doświadczanego dźwięku szumu usznego wyznaczanego indywidualnie dla każdego pacjenta. Dźwięki o natężeniu $80 \mathrm{~dB}$ SPL(C) prezentowane były obuusznie w pseudolosowej kolejności. Badanie wykonano na skanerze Magnetom Trio 3T z użyciem paradygmatu typu SPARSE.

Wyniki: W badanej grupie pacjentów częstotliwość szumu usznego była na poziomie $10,3 \pm 3,5 \mathrm{kHz}$. Nie zaobserwowano różnic w aktywności kory słuchowej w obu badanych grupach dla częstotliwości 400-3200 Hz. Niewielkie różnice były widoczne dla częstotliwości $6400 \mathrm{~Hz}$, natomiast zaobserwowano, że dla częstotliwości zbliżonej do szumu usznego pacjenci mieli znacznie większy obszar aktywności niż osoby bez szumu usznego.

Wnioski: Badania przeprowadzone na pacjentach ze słuchem normalnym $\mathrm{z}$ występującym przewlekłym szumem usznym sugerują, że obszar aktywności w obszarze pierwotnej kory słuchowej ulega reorganizacji tylko w zakresie częstotliwości zbliżonych do występującego szumu usznego.

\section{7 maja 2014 r., sobota}

\section{Sesja XIV}

\section{Wysokoczęstotliwościowe ubytki słuchu u dzieci szkolnych}

\section{Anna Piotrowska, Anna Zapert, Krzysztof Tarczyński, Alicja Danielewicz, Henryk Skarżyński}

Światowe Centrum Stuchu Instytutu Fizjologii i Patologii Stuchu, Warszawa/Kajetany

Słowa kluczowe: niedosłuch • ubytki wysokoczęstotliwościowe • audiometria tonalna $\bullet$ dzieci szkolne

Wprowadzenie: Prawidłowy słuch jest istotny dla rozwoju mowy i języka. Ubytki słuchu mogą wystąpić w każdym wieku, jednak największy problem stanowią wówczas, kiedy dotyczą dzieci. Jedną z przyczyn wystąpienia niedosłuchu u dzieci w wieku szkolnym może być narażenie na nadmierny hałas. Pohałasowe uszkodzenie słuchu w początkowym etapie dotyczy wysokich częstotliwości. Wczesne wykrycie wysokoczęstotliwościowych zaburzeń słuchu u dzieci oraz podjęta odpowiednio wcześnie właściwa interwencja mogą w istotny sposób ograniczyć progresję niedosłuchu oraz jego negatywne następstwa. Celem pracy była ocena częstości występowania wysokoczęstotliwościowych ubytków słuchu u uczniów klas I i VI.
Materiał i metody: Badaniami objęto 82 uczniów klas I i VI szkoły podstawowej, w tym 38 uczniów klas I (46\%) i 44 uczniów klas VI (54\%). U każdego dziecka wykonano audiometryczne badanie słuchu (przewodnictwo powietrzne i kostne) prawego i lewego ucha, dla tonów o częstotliwościach: 0,$5 ; 1 ; 2 ; 3 ; 4 ; 6 ; 8 ; 16 ; 20 \mathrm{kHz}$. Pomiary wykonywano metodą Carhart-Jerger, w kabinie audiometrycznej na audiometrze Madsen Astera z zestawem słuchawkowym Sennheiser HDA 200. Wynik badania uznawano za prawidłowy, jeżeli próg słyszenia dla przewodnictwa powietrznego w zakresie częstotliwości od $0,5 \mathrm{kHz}$ do $20 \mathrm{kHz}$ nie przekraczał $20 \mathrm{~dB}$ HL oraz wartość rezerwy nie była większa niż $15 \mathrm{~dB}$ HL.

Wyniki: W badanej grupie niedosłuch stwierdzono u 46 dzieci (56\%), w tym u 26 uczniów klas I (56\%), 20 uczniów klas VI (44\%). U 27 dzieci (44\% uczniowie klas I, 56\% uczniowie klas VI) ubytek słuchu występował tylko na częstotliwości $6 \mathrm{kHz}$. W grupie dzieci z ubytkiem tylko dla $6 \mathrm{kHz} 26 \%$ stanowiły ubytki obustronne.

Wnioski: Z uwagi na dużą częstość ubytków słuchu występujących tylko na częstotliwości $6 \mathrm{kHz}$ powinno się rozważyć wykonywanie pomiaru na tej częstotliwości podczas realizacji badań przesiewowych słuchu w szkołach. 


\section{Ocena powtarzalności wyników testu rozdzielnousznego cyfrowego (DDT) u dzieci w wieku szkolnym}

\author{
Karolina Dajos-Krawczyńska ${ }^{1}$, \\ Krzysztof Kochanek ${ }^{1}$, Adam Piłka ${ }^{1}$, \\ Katarzyna Biegun ${ }^{2}$, Henryk Skarżyński ${ }^{1}$
${ }^{1}$ Światowe Centrum Stuchu, Instytut Fizjologii i Patologii Stuchu, Warszawa/Kajetany
${ }^{2}$ Zakład Logopedii i Językoznawstwa Stosowanego, UMCS, Lublin

Słowa kluczowe: powtarzalność • słyszenie rozdzielnouszne • DDT

\begin{abstract}
Wprowadzenie: Testy słyszenia rozdzielnousznego pierwotnie stosowane były w celu oceny procesów uwagi. Obecnie często używane są do oceny funkcji wykonawczych i kontroli poznawczej, a także asymetrii słuchowej, która może być wskaźnikiem lateralizacji funkcjonalnej półkul mózgowych. Testy słyszenia rozdzielnousznego stosowane są również do diagnostyki ośrodkowych zaburzeń słuchu. Za ich pomocą można ocenić procesy integracji słuchowej, separacji międzyusznej i krótkotrwałej pamięci słuchowej. Chociaż testy słyszenia rozdzielnousznego są powszechnie stosowane, ich wiarygodność (powtarzalność) jest przedmiotem dyskusji. Celem pracy była ocena powtarzalności rozdzielnousznego testu cyfrowego w grupie dzieci w wieku szkolnym.
\end{abstract}

Material i metody: Badania przeprowadzono w grupie 49 dzieci w wieku 7 i 12 lat o prawidłowej czułości słuchu. Test rozdzielnouszny cyfrowy (DDT, ang. Dichotic Digit Test) wykonano za pomoca programu komputerowego APD (Auditory Processing Disorders) zainstalowanego na komputerze typu notebook wyposażonym w słuchawki nauszne Sennheiser HDA 200. Badanie przeprowadzono trzykrotnie.

Wyniki: Wykazano istotny wpływ wieku na wyniki testu DDT - dzieci młodsze uzyskały niższy średni odsetek prawidłowo powtórzonych cyfr w porównaniu z dziećmi starszymi. W obu grupach wiekowych średni odsetek prawidłowo rozpoznanych cyfr był większy w uchu prawym niż w uchu lewym. Korelacja pomiędzy wynikami kolejnych badań była wysoka. Nie stwierdzono istotnego wpływu wieku, płci i badanego ucha na powtarzalność wyników testu DDT.

Wnioski: Na podstawie analizy wyników stwierdzono, że w obu grupach wiekowych wyniki testu DDT są powtarzalne. Test rozdzielnouszny cyfrowy daje wiarygodne wyniki i może być używany w badaniach klinicznych ośrodkowych zaburzeń słuchu.
Ocena przydatności różnych metod elektrofizjologicznych w wykrywaniu pozaślimakowych zaburzeń słuchu

\section{Lech Śliwa, Krzysztof Kochanek, Adam Piłka, Henryk Skarżyński}

Światowe Centrum Stuchu, Instytut Fizjologii i Patologii Stuchu, Warszawa/Kajetany

Słowa kluczowe: słuchowe potencjały wywołane $\bullet$ pozaślimakowe zaburzenia słuchu • metody elektrofizjologiczne

Metody elektrofizjologiczne, oparte na badaniu słuchowych potencjałów wywołanych (ABR), mogą być cennym narzędziem we wczesnej diagnostyce zaburzeń słuchu typu pozaślimakowego. Czułość metody standardowej, wykorzystującej potencjały wywołane trzaskiem, jest wysoka w przypadku dużych guzów $(>1 \mathrm{~cm})$, lecz maleje, gdy rozmiar nerwiaka jest mniejszy. $W$ ostatnich latach opracowano nowe metody elektrofizjologiczne, o znacznie większej skuteczności. Celem badań było porównanie właściwości trzech metod elektrofizjologicznych (i) metody standardowej, wykorzystującej potencjały ABR wywołane trzaskiem, (ii) metody, w której wykorzystuje się bodźce o postaci krótkich tonów, (iii) metody stosu (Stacked ABR) opracowanej przez M. Dona i wsp. W badaniach uczestniczyła grupa ok. 200 pacjentów Instytutu Fizjologii i Patologii Słuchu z podejrzeniami zaburzeń pozaślimakowych, oraz grupa kontrolna, ok. 50 osób normalnie słyszących, otologicznie zdrowych. U wszystkich badanych wykonano badanie obrazowe MRI z kontrastem oraz testy elektrofizjologiczne trzema wymienionymi metodami. Porównując wyniki badań MRI (metoda odniesienia) z wynikami testów, dla każdej z metod elektrofizjologicznych wyznaczono czułość, specyficzność i wartości predykcyjne. Stwierdzono, że metoda stosu zapewnia bardzo wysoką czułość, lecz przy wartościach normatywnych stosowanych w jedynej dostępnej aplikacji tej metody (w systemie AEP NavPro f-mu Bio-logic Natus) jej specyficzność i wartości predykcyjne są bardzo niskie. Metoda standardowa odznacza się wysoką specyficznością, lecz przy niewielkich zmianach pozaślimakowych ma małą czułość. Metoda wykorzystująca krótkie bodźce tonalne zapewnia dobra czułość przy wysokiej specyficzności. Za optymalny schemat postępowania uznano procedurę dwuetapową, wykorzystującą metodę standardową uzupełnioną badaniem przy użyciu krótkich tonów. Metoda stosu jest mało przydatna z uwagi na bardzo małą wartość predykcyjną, skomplikowaną procedurę i znaczną niepewność pomiaru. 


\section{Ocena progu słyszenia metodą ABR} z wykorzystaniem sygnału typu chirp

\section{Marika Kruszyńska ${ }^{1}$, Krzysztof Kochanek ${ }^{1,2}$, Lech Śliwa ${ }^{2}$, Adam Piłka ${ }^{2}$}

${ }^{1}$ Uniwersytet Marii Curie-Skłodowskiej, Lublin

${ }^{2}$ Światowe Centrum Stuchu, Instytut Fizjologii i Patologii

Stuchu, Warszawa/Kajetany

\section{Słowa kluczowe: ABR • bodziec typu CHIRP}

Wprowadzenie: Metoda wyznaczania progów słyszenia za pomocą ABR jest stosowana w praktyce klinicznej już od wielu lat. Standartowym bodźcem wykorzystywanym do badań jest trzask, przy czym w badaniach stosuje się również krótkie tony o częstotliwościach $500 \mathrm{~Hz}$ i $1000 \mathrm{~Hz}$. Od kilku lat prowadzone są prace nad zastosowaniem bodźca typu CHIRP w badaniach przesiewowych słuchu oraz do oznaczania progu fali V. Z prac różnych autorów wynika, że amplituda fali V dla bodźca typu CHIRP jest większa niż dla trzasku, co może ułatwić jej identyfikację, szczególnie dla natężeń okołoprogowych. Celem pracy byłą ocena progu słyszenia metodą ABR z wykorzystaniem sygnału typu CHIRP.

Material i metody: Materiał pracy obejmował grupę 10 kobiet w wieku 23 lat z normalną czułością słuchu. Badania ABR wykonano za pomocą urządzenia Eclipse EP25. Odpowiedzi ABR rejestrowano procedurą szeregu natężeniowego dla trzasku, krótkiego tonu o częstotliwości $1000 \mathrm{~Hz}$ oraz dla bodźca typu CHIRP - szerokopasmowego oraz o częstotliwości środkowej $1000 \mathrm{~Hz}$.

Wyniki: Analiza wyników wykazała, że amplituda odpowiedzi ABR dla bodźca typu CHIRP CE jest większa niż dla trzasku. Podobne zależności uzyskano przy porównaniu amplitud fali $\mathrm{V}$ dla krótkiego tonu o częstotliwości $1000 \mathrm{~Hz}$ i bodźca CHIRP TB $1000 \mathrm{~Hz}$. Uzyskano wysoką zgodność progu fali $\mathrm{V}$ dla wszystkich bodźców $\mathrm{z}$ audiometrycznym progiem słyszenia.

Wnioski: Na podstawie uzyskanych wyników sformułowano wniosek, że większa amplituda fali $\mathrm{V}$ w odpowiedziach dla bodźca typu CHIRP może ułatwić oznaczenie progu słyszenia za pomocą metody ABR, szczególnie w przypadku osób z prawidłowym słuchem.
Przestrzenne tympanogramy - nowe trendy w diagnostyce audiologicznej

Barbara Bilińska, Katarzyna Paluszak, Anna Hashimoto, Piotr Swidziński, Bogna Małaczyńska

Katedra i Klinika Foniatrii i Audiologii, UM w Poznaniu

Słowa kluczowe: tympanometria • absorbancja

Badanie tympanometryczne stanowi wynik pomiaru akustycznego struktur ucha środkowego; jest zależnością jego impedancji w funkcji zmian ciśnienia powietrza. Obecnie pojawiły się nowe możliwości rejestracji tympanogramów - tympanogramy przestrzenne (WBT - Wideband Tympanometry), w których rejestruje się absorbancję w zależności od częstotliwości i ciśnienia. W pomiarach WBT jako tonu próbnego używa się trzasku, w zakresie częstotliwości $226 \mathrm{~Hz}$ do $8000 \mathrm{~Hz}$, zamiast tonu próbnego o częstotliwości najczęściej $226 \mathrm{~Hz}$. W zależności od rodzaju schorzenia ucha środkowego zmienia się absorbancja. W pracy pokazano rozkład absorbancji w funkcji częstotliwości dla różnych schorzeń ucha środkowego. Poprzez pomiar absorbancji tympanometria WBT dostarcza informacji, które pomagają odróżnić prawidłowe funkcjonowanie ucha środkowego od patologii takich jak: wysiękowe zapalenie, otoskleroza, przerwanie łańcucha kosteczek. Tympanometria WBT rozszerza wiedzę o dyskretnych zmianach absorbancji związanych ze zmianami bliznowatymi błony bębenkowej.

\section{Wpływ ustawienia optyki w czasie badania laryngovideostroboskopowego na interpretację czynności krtani}

\author{
H. Mackiewicz-Nartowicz ${ }^{1,2}$, A. Sinkiewicz ${ }^{1,2}$, \\ M. Just ${ }^{1,2}$, M. Zacirka ${ }^{1,2}$, A. Lewandowski ${ }^{1,2}$, \\ P. Winiarski ${ }^{1,2}$

\footnotetext{
${ }^{1}$ Klinika Foniatrii i Audiologii, Oddziat Otolaryngologii i Onkologii Laryngologicznej z Pododziatem Chirurgii Szczękowej, Szpital Uniwersytecki nr 2, Bydgoszcz
} \\ ${ }^{2}$ DiagNova Technologies Wrocław
}

Celem pracy była ocena wpływu skręcenia optyki sztywnej endoskopu podczas badania laryngovideostroboskopowego na interpretację obrazów krtani, a zwłaszcza na interpretację przekrojów kimograficznych uzyskanych w trakcie badania. Dokonano oceny badań laryngovideostroboskopowych wykonanych u 20 zdrowych osób przy różnym ustawieniu optyki sztywnej endoskopu. Badania potwierdziły wcześniejsze obserwacje, że obrócenie optyki w osi endoskopu powoduje wrażenie pozornego przesunięcia fazy pomiędzy ruchem fonacyjnym obu fałdów głosowych. Zjawisko to obserwowane jest głównie w niskich zakresach częstotliwości fonacji. Uzyskane w ten sposób obrazy mogą sugerować nieistniejącą patologię funkcji krtani. 


\section{Sesja plakatowa}

\section{Strategie radzenia sobie ze stresem u osób z głuchotą prelingwalną korzystających z implantu ślimakowego od wczesnej dorosłości}

Joanna Kobosko, Edyta Piłka, Agnieszka Pankowska, Henryk Skarżyński

Światowe Centrum Stuchu, Instytut Fizjologii i Patologii Słuchu, Warszawa/Kajetany

Słowa kluczowe: głuchota prelingwalna • zdrowie psychiczne • implant ślimakowy

Wprowadzenie: Strategie radzenia sobie ze stresem u osób z głuchotą prelingwalną nie były jak dotąd przedmiotem badań psychologicznych. Ocena skuteczności radzenia sobie w konfrontacji ze stresem ogrywa ważną rolę w przypadku osób z niepełnosprawnością, jaką jest głuchota prelingwalna, jak i pozwala na zaproponowanie adekwatnej oferty w zakresie rehabilitacji słuchu i mowy, w tym interwencji psychologicznej. Celem badań jest porównanie osób dorosłych prelingwalnie ogłuchłych z implantem ślimakowym (CI) z osobami słyszącymi w zakresie strategii radzenia sobie ze stresem (coping) $\mathrm{z}$ uwzględnieniem czasu korzystania z CI, znajomości języka migowego oraz zmiennych socjodemograficznych.

Material i metody: Badania przeprowadzono drogą pocztową i objęto 79 osób z głuchotą prelingwalną w wieku od 19 do 62 lat z CI, dla których wskaźnik odpowiedzi zwrotnych wynosił $63,3 \%$, oraz osoby słyszące. Wykorzystano Ankietę i kwestionariusz Mini-COPE.

Wyniki: Osoby z głuchotą prelingwalną z CI rzadziej niż osoby słyszące stosują aktywne radzenie sobie ze stresem, także rzadziej sięgają po substancje psychoaktywne, natomiast częściej zaprzestają działań. Płeć, wiek, status małżeński (partnerski), jak i praca odgrywają istotną rolę w sferze wykorzystywanych strategii coping. Dłuższy czas korzystania z CI wiąże się z rzadszym obwinianiem siebie i kierowaniem się ku religii. Znajomość języka migowego istotnie sprzyja mniej częstemu posługiwaniu się strategią wyładowania w konfrontacji ze stresem.

Wnioski: Strategie radzenia sobie ze stresem, jakimi posługują się osoby prelingwalnie ogłuchłe z CI, znacząco odróżniają je od osób słyszących, ale także i od osób postlingwalnie ogłuchłych z CI. Nie jest zatem wskazane traktowanie osób z CI jako jednorodnej grupy z pominięciem etiologii głuchoty, szczególnie w planowaniu działań rehabilitacyjnych, jak i badań naukowych.

\section{Górnośląski Program Implantów Ślimakowych - analiza audiologiczno- -foniatryczna 86 zaimplantowanych pacjentów}

Lucyna Klimczak-Gołąb, Małgorzata Witkowska, Jarosław Markowski, Agnieszka Piotrowska-Seweryn, Elwira Nowak-Adamska, Jan Pilch

Katedra i Klinika Laryngologii. Śląski Uniwersytet Medyczny w Katowicach

W 2003 roku w Klinice Laryngologii Śląskiej Akademii Medycznej rozpoczęto program leczenia całkowitej obustronnej głuchoty metodą wielokanałowych wszczepów ślimakowych. Program ten wychodzi naprzeciw potrzebom zdrowotnym około pięciomilionowej populacji Śląska. W trakcie przygotowań zespół kliniki odbył liczne krajowe i zagraniczne szkolenia $\mathrm{z}$ zakresu chirurgii, jak i pooperacyjnej opieki po wszczepieniu implantu. Podjęto działania, które przystosowały zaplecze diagnostyczne do specyficznych wymagań diagnostyki przed implantacją (w zakresie audiologii, radiologii, jak i badania psychologicznego i logopedycznego). Wśród nowości diagnostycznych mających zastosowanie w procesie kwalifikacji chorych do implantacji ślimakowej na wyróżnienie zasługuje doskonała diagnostyka obrazowa wykonywana za pomocą tomografu HRCT z opcja rekonstrukcji 3D. W budynku kliniki znajduje się ośrodek rehabilitacji Śląskiego Oddziału Polskiego Związku Głuchych. Dobra baza lokalowa oraz łatwość bezpośredniego kontaktu klinicystów i rehabilitantów niewątpliwie pozytywnie wpływa na proces rehabilitacji chorych. Przy kwalifikacji do wszczepu przyjęto powszechnie stosowane standardy: badanie podmiotowe i przedmiotowe, badania audiologiczne, badania obrazowe, konsultacje lekarzy innych specjalności, ocena psychologiczna i logopedyczna. Do chwili obecnej w Klinice Laryngologii SUM wykonano 86 operacji wszczepienia wielokanałowego implantu ślimakowego. We wszystkich przypadkach zastosowano typowa technike operacyjna. W trakcie wszystkich zabiegów wykonujemy: pomiary impedancji elektro, pomiar SRT dla co drugiej elektrody, pomiar NRT dla co drugiej elektrody. W pracy dokonano analizy audiologicznej i foniatrycznej zaimplantowanych chorych. 


\section{Doświadczanie objawów depresji a strategie radzenia sobie ze stresem i samoocena u osób dorosłych $\mathrm{z}$ głuchotą prelingwalną zaopatrzonych $\mathrm{w}$ implant ślimakowy po 18 roku życia}

\section{Joanna Kobosko, Anna Geremek-Samsonowicz, Henryk Skarżyński}

Światowe Centrum Stuchu, Instytut Fizjologii i Patologii Stuchu, Warszawa/Kajetany

\section{Słowa kluczowe: implant ślimakowy • depresja}

Występowanie problemów ze zdrowiem psychicznym u osób dorosłych z głuchotą prelingwalną jest wyższe niż w populacji osób słyszących, niezależnie od preferowanego sposobu komunikowania się z otoczeniem. Brak jest wciąż badań dotyczących użytkowników implantu ślimakowego z głuchotą prelingwalną, które otrzymały implant ślimakowy po 18 r.ż. Celem badań jest odpowiedź na pytanie o nasilenie doświadczanych objawów depresji u osób prelingwalnie ogłuchłych z CI, w porównaniu ze słyszącymi, a także o to, jakie strategie radzenia sobie ze stresem pozostają w związku z nasileniem objawów depresji. Kolejne pytanie dotyczy samooceny i nasilenia objawów depresji. Ciekawe jest także, na ile strategie radzenia sobie ze stresem, samoocena, a także zmienne socjodemograficzne objaśniają doświadczane nasilenie symptomów depresji u osób z głuchotą postlingwalną z CI, jak i słyszących. Badaniami objęto osoby $\mathrm{z}$ głuchotą prelingwalną, zaimplantowane w roku 2005 i 2009. Zastosowano kwestionariusz GHQ-28 (Skala D), inwentarz do pomiaru strategii radzenia sobie ze stresem Mini-COPE, Skalę Samooceny SES Rosenberga oraz Ankietę informacyjną. Okazało się, że osoby z głuchotą prelingwalną z CI doświadczają w większym nasileniu (na poziomie tendencji statystycznej) objawów depresji w porównaniu ze słyszącymi. Z większym nasileniem objawów depresji pozostaje $\mathrm{u}$ nich w związku rzadsze stosowanie strategii skoncentrowanych na problemie: aktywne radzenie sobie i planowanie, a także częstsze zaprzestanie działań. Istotnymi predyktorami nasilenia objawów depresji są: zaprzestanie działań, akceptacja i zażywanie substancji psychoaktywnych. Podjęte zagadnienie wymaga dalszych badań populacji, jaką stanowią osoby dorosłe $\mathrm{z}$ głuchotą prelingwalną, zaopatrzone w implant ślimakowy po 18 roku życia, $\mathrm{z}$ uwzględnieniem zmiennej, jaką są kompetencje językowe badanych w języku fonicznym. Rezultaty sugerują, iż zażywanie substancji psychoaktywnych jest jedynie $\mathrm{w}$ tej grupie istotnym predyktorem objawów depresyjnych.

\section{Ocena powtarzalności badań audiometrycznych wykonywanych w szkołach}

\author{
Paulina Dziedzic ${ }^{1}$, Adam Piłka ${ }^{2}$, \\ Krzysztof Kochanek $^{1,2}$, Henryk Skarżyński ${ }^{2}$
}

\section{${ }^{1}$ Zakład Logopedii i Językoznawstwa Stosowanego, UMCS, Lublin \\ ${ }^{2}$ Światowe Centrum Stuchu, Instytut Fizjologii i Patologii Stuchu, Warszawa/Kajetany}

Słowa kluczowe: badania przesiewowe słuchu • audiometria tonalna $\bullet$ powtarzalność

Wprowadzenie: Kontrolowanie słuchu u dzieci umożliwia nie tylko wczesne wykrycie zaburzeń słuchu, ale co najważniejsze wdrożenie odpowiedniej terapii, która zapewnienia możliwość prawidłowego rozwoju dziecka. Badania przesiewowe słuchu powinny obejmować nie tylko noworodki, lecz także dzieci w wieku przedszkolnym i szkolnym, ponieważ pozwalają one na wykrycie nie tylko wrodzonych, lecz także nabytych wad słuchu. Celem pracy była ocena powtarzalności audiometrycznych badań przesiewowych u dzieci w wieku szkolnym.

Materiał i metody: Badaniami objęto grupę 23 dzieci w wieku 6-7 lat i 23 dzieci między 12 a 13 rokiem życia które uczęszczają do szkoły podstawowej. U wszystkich osób wykonano trzykrotny pomiar progu słyszenia, w losowo wybranym uchu. Badania wykonywano w odstępach dwudniowych, o tej samej porze dnia, w tym samym pomieszczeniu. Pomiary prowadzono procedurą góra-dół dla przewodnictwa powietrznego dla częstotliwości 500, 1000, 2000, 4000 i $8000 \mathrm{~Hz}$. Analizę wyników badań przeprowadzono z wykorzystaniem Bazy Wiedzy - naukowej platformy informatycznej przetwarzania wyników badań przesiewowych Instytutu Fizjologii i Patologii Słuchu. Analizowano wpływ wieku dziecka oraz kolejnych pomiarów na wartości progu słyszenia dla poszczególnych częstotliwości. Na podstawie uzyskanych wartości wyznaczono różnicę progu słyszenia, odejmując od wartości progu słyszenia uzyskanego $\mathrm{w}$ drugim i trzecim pomiarze, wartość progu słyszenia uzyskanego podczas pierwszego pomiaru. Dodatkowo przeprowadzono również ocenę czasu trwania badania w kolejnych próbach.

Wyniki: W obu grupach dzieci średnie wartości progu słyszenia dla poszczególnych częstotliwości, wyznaczone podczas trzeciego badania, były mniejsze niż w badaniach pierwszym i drugim. Czas pomiarów w kolejnych próbach uległ skróceniu.

Wnioski: Przeprowadzone badania pokazały, że u dzieci $\mathrm{w}$ wieku szkolnym możliwe jest wykonanie wiarygodnego badania audiometrycznego już przy pierwszym pomiarze. 


\section{Ocena powtarzalności wyników testów ośrodkowych funkcji słuchowych u dzieci w wieku szkolnym}

\section{Katarzyna Biegun', Krzysztof Kochanek ${ }^{2}$, Adam Piłka $^{2}$, Karolina Dajos-Krawczyńska ${ }^{2}$, Henryk Skarżyński ${ }^{2}$}

\author{
${ }^{1}$ Zakład Logopedii i Językoznawstwa Stosowanego, UMCS, \\ Lublin \\ ${ }^{2}$ Światowe Centrum Słuchu, Instytut Fizjologii i Patologii \\ Stuchu, Warszawa/Kajetany
}

Słowa kluczowe: powtarzalność • rozumienie mowy w szumie • FPT • GDT • aSPN

Wprowadzenie: Diagnoza ośrodkowych zaburzeń słuchu obejmuje wykonanie testów behawioralnych i elektrofizjologicznych pozwalających na ocenę różnych funkcji słuchowych. Istnieje wiele testów behawioralnych stosowanych w diagnostyce i badaniach przesiewowych zaburzeń przetwarzania słuchowego, jednak nie dla wszystkich testów określona została czułość i specyficzność. Ważne jest, aby testy określone mianem diagnostycznych dawały wiarygodne - a zatem powtarzalne - wyniki. Celem pracy była ocena powtarzalności wyników wybranych testów ośrodkowych funkcji słuchowych u dzieci w wieku szkolnym.

Material i metody: Badaniami objęto grupę 49 uczniów w wieku 7 i 12 lat, uczęszczających do klasy pierwszej i szóstej szkoły podstawowej. U każdego dziecka przeprowadzono badanie audiometrii tonalnej dla częstotliwości 250-8000 Hz. Do oceny ośrodkowych funkcji słuchowych wykorzystano testy: adaptacyjny test rozumienia mowy w szumie (aSPN - ang. adaptive Speech in Noise), test oceny wzorców częstotliwości (FPT - ang. Frequency Pattern Test) oraz test wykrywania przerw (GDT - ang. Gap Detection Test). U każdego dziecka badania wykonywano trzykrotnie - drugie badanie przeprowadzano po godzinie od pierwszego, natomiast trzecie po upływie 2 tygodni.

Wyniki: Analiza statystyczna nie wykazała wpływu wieku i płci badanych osób na wyniki testów GDT i FPT. Korelacja pomiędzy wynikami kolejnych testów GDT i FPT była wysoka. Wiek wpływa na wyniki testu aSPN - dzieci młodsze uzyskują słabsze wyniki niż dzieci starsze. Korelacja pomiędzy wynikami kolejnych badań aSPN jest niska.

Wnioski: Testy GDT i FPT w obu grupach wiekowych odznaczają się wysoką powtarzalnością, co oznacza, że dają wiarygodne wyniki i mogą być stosowane jako testy przesiewowe i diagnostyczne zaburzeń przetwarzania słuchowego. Przy analizie wyników testu aSPN należy zwrócić szczególną uwagę na czynniki (wiek, badane ucho), które mogą wpływać na uzyskane wyniki.

\section{Ocena stanu słuchu u studentów lubelskich} uczelni

\author{
Anna Dębiec', Adam Piłka ${ }^{2}$, \\ Wiesław Wiktor Jędrzejczak ${ }^{2}$, \\ Krzysztof Kochanek $^{1,2}$, Henryk Skarżyński ${ }^{2}$
}
${ }^{1}$ Zakład Logopedii i Językoznawstwa Stosowanego, UMCS, Lublin
${ }^{2}$ Światowe Centrum Słuchu, Instytut Fizjologii i Patologii Stuchu, Warszawa/Kajetany

Słowa kluczowe: badanie słuchu • studenci

Wprowadzenie: Prawidłowo funkcjonujący narząd słuchu odgrywa ogromną rolę w procesie zdobywania wiedzy i informacji. Niewiele jednak badań przeprowadzono w grupach młodych osób dorosłych. Badania wykazują, że częstość występowania niedosłuchów u młodych ludzi wzrasta. Celem pracy była ocena stanu słuchu w grupie studentów lubelskich uczelni wyższych. Grupa badawcza obejmowała 100 osób, w tym 52 kobiety i 48 mężczyzn, w wieku od 19 do 31 lat. Wszyscy badani byli studentami lubelskich uczelni wyższych. Ocena audiologiczna obejmowała audiometrię tonalną, audiometrię impedancyjną oraz pomiar emisji otoakustycznych. Dodatkowo każdy uczestnik wypełniał ankietę.

Wyniki: Analiza ankiety wykazała, że 94,5\% studentów ocenia swój słuch jako prawidłowy. Subiektywne odczuwanie niedosłuchu sygnalizowane $\mathrm{w}$ ankiecie (5,5\% wszystkich badanych) nie miało odzwierciedlenia w wynikach badania audiometrii tonalnej. Najczęstszym problem słuchowym zgłaszanym przez studentów były trudności w rozumieniu mowy w hałasie. Liczba wykrytych niedosłuchów zmienia się, w zależności od zastosowanej klasyfikacji zaburzeń słuchu. Zgodnie z kryterium BIAP oraz WHO, wszystkie wyniki badania audiometrii tonalnej w grupie studentów były w normie. Natomiast w przypadku zastosowania klasyfikacji ANSI, poszerzonej o wartości progów dla częstotliwości półoktawowych, odsetek osób z niedosłuchem wyniósł 18\%. 91\% badanych osób miało tympanogram typu A. Natomiast otoemisje akustyczne wywołane trzaskiem (TEOAE) i spontaniczne (SOAE) występowały odpowiednio u 93\% i 67\% studentów. Obniżenie amplitudy otoemisji akustycznych, bądź ich całkowity brak u niektórych osób, może świadczyć o zaburzeniach prawidłowego funkcjonowania mikromechanizmów ślimaka, powstałych w wyniku ekspozycji na hałas.

Wnioski: Stan słuchu większości studetów znajduje się w zakresie normy, przy czym u części osób, na podstawie zastosowanej klasyfikacji ANSI, rozpoznano niedosłuch, niepowodujący jednak subiektywnego odczuwania niedosłuchu u badanych studentów. 


\section{Ocena wpływu hałasu szkolnego na wyniki testów centralnych funkcji słuchowych}

\section{Lucyna Fajdek ${ }^{1}$, Krzysztof Kochanek ${ }^{2}$, Adam Piłka ${ }^{2}$, Henryk Skarżyński ${ }^{2}$}

\section{${ }^{1}$ Zakład Logopedii i Językoznawstwa Stosowanego, Wydziat Humanistyczny, UMCS, Lublin \\ ${ }^{2}$ Światowe Centrum Stuchu, Instytut Fizjologii i Patologii Stuchu, Warszawa/Kajetany}

Słowa kluczowe: hałas w szkole • rozumienie mowy w szumie $\bullet$ zaburzenia przetwarzania słuchowego $\bullet$ wpływ hałasu

Wprowadzenie: Celem pracy była ocena wpływu hałasu panującego podczas długich przerw międzylekcyjnych na wyniki testów centralnych funkcji słuchowych u dzieci.

Materiał i metody: Badaniami objęto grupę 19 uczniów w wieku 10 lat. Badania wykonywane były dwukrotnie przed rozpoczęciem zajęć lekcyjnych oraz po kilku godzinach zajęć, tuż po zakończeniu długiej przerwy międzylekcyjnej (25 min). Badania prowadzono za pomoca testu słyszenia rozdzielnousznego - DDT, testu rozumienia mowy w szumie - aSPN oraz testu wykrywania przerw w szumie - GDT.

Wyniki i wnioski: Na podstawie wyników przeprowadzonych badań można stwierdzić, iż ekspozycja na hałas szkolny $\mathrm{w}$ trakcie przerw międzylekcyjnych nie wpływa znacząco na wyniki stosowanych w pracy testów psychoakustycznych. Brak wpływu hałasu na wyniki testów centralnych funkcji słuchowych spowodowany był najprawdopodobniej zbyt krótkim czasem ekspozycji na hałas.

\section{Słuchanie głośnej muzyki w słuchawkach a szumy uszne u dzieci}

\section{Jan Aleszczyk, Oleh Chorow, Tamara Jucewicz, Siergej Kosciukowicz, Oksana Kryniec}

Uniwersytet Medyczny w Grodnie, Białoruś

Słowa kluczowe: szumy uszne u dzieci • głośna muzyka • słuchawki

Wprowadzenie: Problem szumów usznych stale rośnie ze względu na rozwój technologiczny, zwiększenie tempa życia i i narażenie na stres. W ostatnich latach rośnie liczba dzieci cierpiących z powodu szumów usznych. Poszukuje się najbardziej prawdopodobnych przyczyn tego zjawiska. Celem pracy było zbadanie częstości występowania i przyczyn szumów usznych u dzieci w wieku szkolnym (od 8 do 17 lat).

Materiał i metody: Przeprowadzono badanie dzieci w szkołach w Grodnie (szum w uszach, związek z warunkami życia, pogorszenie jakości życia). Zbadano 1158 dzieci w wieku od 8 do 17 lat. Wśród nich: grupa 1 - dzieci w wieku 8-11 lat (230 (19,9\%) osób), grupa 2 - dzieci w wieku 12-13 lat (226 (19,5\%) osób), grupa 3 - dzieci w wieku $14-15$ lat $(432(37,3 \%)$ osoby), grupa $4-$ dzieci w wieku 16-17 lat (270 (23,3\%) osób).
Wyniki: Wśród wszystkich przebadanych dzieci odnotowano szumy uszne odnotowano u 553 dzieci, co stanowiło $47,8 \%$. Szum w grupie 1 potwierdziło $75(32,6 \%)$ dzieci, w grupie 2 - 95 (42\%) dzieci, w grupie $3-232(53,7 \%)$ dzieci, w grupie 4 - 151 (55,9\%) dzieci. Spośród wszystkich dzieci z szumami usznymi głośnej muzyki i muzyki przez słuchawki słuchało $406(63,4 \%)$ dzieci. W grupie 1 - $52(69,3 \%)$ dzieci, w grupie $2-61(64,2 \%)$ dzieci, w grupie 3 - $167(72 \%)$ dzieci, w grupie $4-138(91,4 \%)$ dzieci. Wraz z wiekiem dzieci wzrasta częstość wykorzystania słuchawek podczas słuchania muzyki, które mają bezpośredni wpływ na pojawienie szumów usznych. Wpływ szumów usznych na jakość życia, ocenianego w ramach dziesięciopunktowej skali, dzieci szacują średnio na 1,92 $\pm 0,29$ pkt. Jednakże 47 (4\%) dzieci stwierdziło pogorszenia jakości życia, oceniając ją w zakresie od 4 do 8 punktów.

Wnioski: 1. Prawie połowa badanych dzieci $(47,8 \%)$ odczuwa szumy w uszach. 2. Częstotliwość szumów usznych wzrasta wraz $\mathrm{z}$ wiekiem, co jest bezpośrednio związane z liczbą dzieci często słuchających głośnej muzyki i muzyki przez słuchawki. 3. Stopień wpływu szumów usznych na

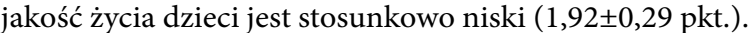

\section{Górnośląski Program Wszczepiania Implantów Zakotwiczonych w Kości Skroniowej - analiza audiologiczna zaimplantowanych chorych}

\section{Aleksandra Ślaska-Kaspera, Katarzyna Przytuła-Kandzia, Jarosław Markowski, Jarosław Paluch}

Katedra i Klinika Laryngologii, SPSKM im. A. Mielęckiego ŚUM, Katowice

Słowa kluczowe: bezpośrednie przewodnictwo kostne • niedosłuch mieszany $\bullet$ niedosłuch przewodzeniowy $\bullet$ jednostronna głuchota odbiorcza (SSD) • implant zakotwiczony w kości skroniowej • kwestionariusz Glasgow Benefit Inventory

Wprowadzenie: Implanty zakotwiczone w kości skroniowej na przewodnictwo kostne to sprawdzony i skuteczny sposób leczenia niedosłuchów. Zgodnie $\mathrm{z}$ aktualnym stanem wiedzy wskazania do wszczepienia implantów zakotwiczonych w kości skroniowej obejmują: niedosłuch typu przewodzeniowego (jednostronny i obustronny), niedosłuch typu mieszanego (jednostronny i obustronny) oraz jednostronną głuchotę odbiorczą. Celem pracy jest przedstawienie doświadczeń własnych uzyskanych w Katedrze i Klinice Laryngologii ŚUM w Katowicach.

Materiał i metody: Autorzy analizują wyniki wszczepienia w latach 2008-2014 implantów zakotwiczonych w kości skroniowej na przewodnictwo kostne u 50 chorych, z uwzględnieniem płci, wieku, wskazań audiologicznych, techniki operacyjnej, korzyści audiologicznych oraz na podstawie kwestionariusza GBI.

Wyniki: Przeprowadzona analiza wykazała znaczące korzyści audiologiczne oraz poprawę jakości życia wśród 
pacjentów po wszczepieniu implantu zakotwiczonego w kości skroniowej na przewodnictwo kostne.

\section{Ocena stanu słuchu studentów w zakresie wysokich częstotliwości}

\section{Joanna Pilch ${ }^{1}$, Krzysztof Kochanek ${ }^{1,2}$, Adam Piłka $^{2}$, Henryk Skarżyński ${ }^{2}$}

${ }^{1}$ Uniwersytet Marii Curie-Skłodowskiej

${ }^{2}$ Światowe Centrum Stuchu, Instytut Fizjologii i Patologii Stuchu, Warszawa/Kajetany

Słowa kluczowe: pohałasowe ubytki słuchu

Wprowadzenie: Według WHO (Światowej Organizacji Zdrowia) u około $10-20 \%$ osób poniżej 18 roku życia można stwierdzić początki pohałasowych ubytków słuchu, powstałych w wyniku ekspozycji na hałas rozrywkowy.

Materiał i metody: W przeprowadzanych badaniach uczestniczyło 60 studentów uczelni lubelskich. Osoby te samodzielnie zgłaszały chęć udziału. Badania przeprowadzone były w dopasowanej do tego celu sali pomiarowej, z wykorzystaniem wyspecjalizowanego sprzętu oraz kabiny akustycznej. Każdy uczestnik został poproszony o uzupełnienie ankiety, a następnie był poddany badaniu: audiometrii impedancyjnej, audiometrii tonalnej i wysokoczęstotliwościowej oraz otoemisji akustycznych (TEOAE i DPOAE). Wszystkie pomiary były wykonywane podczas jednego spotkania.

Wyniki: W badanej grupie najczęściej wskazywanym źródłem hałasu był: hałas komunikacyjny, hałas w miejscu zamieszkania oraz hałas związany $\mathrm{z}$ rozrywką. $Z$ przeprowadzonej ankiety wynika, że znaczna liczba osób deklaruje częste słuchanie głośnej muzyki. Badanie audiometrii klasycznej wyłoniło odsetek zaburzeń słuchu porównywalny z częstością zaburzeń słuchu u dzieci i młodzieży szkolnej. Ocena progu słyszenia w zakresie częstotliwości wyższych 8-16 kHz wykazała prawie 2,5 razy więcej wyników nie mieszczących się $\mathrm{w}$ normie słuchowej niż $\mathrm{w}$ audiometrii do $8 \mathrm{kHz}$. Potwierdza to założenie, że audiometria wysokoczęstotliwościowa jest czulszą metodą wykrywania wczesnych zmian w narządzie słuchu niż audiometria klasyczna. Stwierdzono także, że podwyższenie progu słyszenia w zakresie wyższych częstotliwości nie wpływa na zdolności słyszenia w zakresie 125-8000 Hz.

Wnioski: Przedstawiona charakterystyka pohałasowych ubytków słuchu wskazuje na potrzebę przeprowadzania dalszych badań. Uzyskane wyniki korelują z wynikami opisanymi w literaturze. Wskazane jest podjęcie badań na liczniejszych grupach oraz w dłuższym czasie. Niezwykle ważnym aspektem jest także szerzenie wiedzy na temat profilaktyki uszkodzeń z tym związanych.
Obserwacja poprawy funkcji umysłowych metodą Mini-Mental u chorych Oddziału Geriatrycznego po zaprotezowaniu niedosłuchu

\author{
Karolina Pilecka ${ }^{1}$, Alicja Sekula ${ }^{2}$, \\ Jagoda Różycka ${ }^{3,4}$
}

\author{
${ }^{1}$ Kind Aparaty Stuchowe, Poznań \\ ${ }^{2}$ Katedra i Klinika Foniatrii i Audiologii, Uniwersytet Medyczny \\ w Poznaniu \\ ${ }^{3}$ Zakład Psychologii Klinicznej Instytutu Psychologii, Wydział \\ Filozoficzny, Uniwerystet Jagielloński w Krakowie \\ ${ }^{4}$ Oddzial Geriatrii, SP nr 7, Górnośląskie Centerum Medyczne \\ im. Prof. L. Gieca w Katowicach
}

Słowa kluczowe: Mini-Mental • funkcje umysłowe osób starszych • protezowanie słuchu • zdolności kognitywne $\bullet$ niedosłuch

Wprowadzenie: Utrata funkcji poznawczych, obok zmian fizjologicznych, jest głównym problemem pacjentów oddziałów geriatrycznych. Istnieje wiele czynników wpływających na zdolności kognitywne pacjentów w podeszłym wieku. Niewątpliwie jednym $\mathrm{z}$ nich jest fizjologiczny proces starzenia się narządu słuchu, wpływający na zdolność odbierania informacji akustycznych docierających do takich pacjentów. Jedną z metod oceny funkcjonowania poznawczego jest Krótka Skala Oceny Stanu Psychicznego MMSE (Mini-Mental State Examination). Skala ta określa ogólny poziom możliwości poznawczych osoby badanej, wyliczany na podstawie sumy punktów uzyskanych w próbach oceniających poszczególne funkcje poznawcze. Celem pracy była obserwacja poprawy funkcji umysłowych u pacjentów w podeszłym wieku, po zaprotezowaniu niedosłuchu aparatami słuchowymi w interpretacji wstępnej i końcowej Testu Mini-Mental.

Materiał i metody: Badaniami objęto grupę 15 pacjentów Oddziału Geriatrycznego Górnośląskiego Centrum Medycznego o średniej wieku $80 \pm 5$ lat. Każdej osobie badanej wykonano badanie progowe audiometrią tonalną, audiometrię impedancyjną, pomiar otoemisji akustycznych wywołanych trzaskiem oraz audiometrię mowy. Badania wykonano dwukrotnie - przed i po obustronnym zaprotezowaniu aparatami słuchowymi.

Wyniki: Zaobserwowano poprawę funkcji poznawczych po zaprotezowaniu aparatami słuchowymi. u każdej z badanych osób. Analiza wyników testu Mini-Mental przed i po zaprotezowaniu wykazała poprawę funkcjonowania kognitywnego na poszczególnych płaszczyznach.

Wnioski: Ubytki słuchu spowodowane starzeniem się układu słuchowego moga wpływać na funkcjonowanie poznawcze pacjentów geriatrycznych. Obustronne protezowanie aparatami słuchowymi w znacznym stopniu poprawia funkcjonowanie osób w wieku podeszłym. 


\section{Wpływ hałasu dyskotekowego na centralne funkcje słuchowe}

\author{
Sylwia Hajkowska', Krzysztof Kochanek², \\ Adam Piłka², Henryk Skarżyński² \\ ${ }^{1}$ Zakład Logopedii i Językoznawstwa Stosowanego, UMCS, \\ Lublin \\ ${ }^{2}$ Światowe Centrum Stuchu, Instytut Fizjologii i Patologii \\ Stuchu, Warszawa/Kajetany
}

Słowa kluczowe: hałas - zaburzenia przetwarzania słuchowego • rozumienie w szumie • wpływ hałasu • hałas dyskotekowy

Wprowadzenie: Szeroko rozumiany hałas niesie istotne niebezpieczeństwo dla narządu słuchu osób w każdym wie$\mathrm{ku}$. Coraz częściej narażenie na hałas jest związane $\mathrm{z}$ hałasem środowiskowym - preferowaną formą i miejscem spędzania czasu wolnego. Skutkuje to wzrostem uszkodzeń słuchu spowodowanych hałasem u młodych ludzi, w tym młodzieży i dzieci w wieku szkolnym. Niewątpliwie najbardziej czułym organem układu słuchowego na działanie hałasu jest ucho wewnętrzne (w tym szczególnie ślimak). Jak wskazują nieliczne badania, hałas może negatywnie wpływać również na ośrodkowe funkcje słuchowe. Celem pracy była ocena wpływu ekspozycji na hałas dyskotekowy (głośna muzyka) na wyniki testów ośrodkowych funkcji słuchowych.

Materiał i metody: Badaniami objęto grupę 16 kobiet. U każdej osoby wykonano badanie progowej audiometrii tonalnej, tympanometrię oraz testy oceniające ośrodkowe funkcje słuchowe - test wykrywania przerw w szumie GDT, rozdzielnouszny test cyfrowy DDT i adaptacyjny test rozumienia mowy w szumie aSPN. Badania wykonano dwukrotnie - przed i po godzinnej ekspozycji na muzykę o natężeniu $90 \mathrm{dBA}$.

Wyniki: Nie wykazano istotnego wpływu jednogodzinnej ekspozycji na hałas dyskotekowy na wyniki testów GDT oraz DDT. Analiza wykazała, że wyniki testu aSPN po ekspozycji na hałas były gorsze $\mathrm{w}$ porównaniu $\mathrm{z}$ wynikami badania przed ekspozycją.

Wnioski: Krótka ekspozycja na muzykę dyskotekową nie powoduje znaczącego wpływu na wyniki wybranych testów oceniających centralne funkcje słuchowe.

\section{Stan słuchu studentów medycyny a samoocena nawyków słuchania muzyki}

Anna Pajor ${ }^{1}$, Anna Ciesielczuk-Łuczywek ${ }^{2}$, Magdalena Józefowicz-Korczyńska1

\author{
${ }^{1}$ I Katedra Otolaryngologii UM $w$ Łodzi \\ ${ }^{2}$ WOMP-CPL $w$ Łodzi
}

Słowa kluczowe: słuch • studenci medycyny • słuchanie muzyki

Wprowadzenie: Uszkodzenia słuchu pod wpływem hałasu coraz częściej związane są z jego szkodliwym działaniem w otaczającym środowisku i w czasie wypoczynku, w tym z ekspozycją na głośną muzykę. Wśród grup najczęściej narażonych są muzycy, pracownicy ośrodków spotkań muzycznych (kluby, dyskoteki, koncerty) oraz młodzież i młode osoby dorosłe słuchające głośno muzyki i/lub słuchające w osobistych odtwarzaczach muzyki. Celem pracy była ocena słuchu studentów medycyny w zależności od samooceny nawyków słuchania muzyki.

Materiał i metody: W badaniach wzięło udział 100 studen-

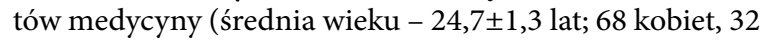
mężczyzn), którzy nie zgłaszali niedosłuchu i u których nie stwierdzono zmian w badaniu otoskopowym. U wszystkich osób wykonano audiometrię tonalną konwencjonalną (AT) i wysokoczęstotliwościową (EHFA), tympanometrię oraz przeprowadzono ankietę dotyczącą m.in. nawyków słuchania muzyki.

Wyniki: Stwierdzono, że 26 osób zgłaszało okresowe szumy uszne, 5 osób - zawroty głowy, 5 osób - nadwrażliwość słuchową, 10 osób - ból uszu w hałasie i 47 osób zmęczenie słuchowe po ekspozycji na hałas. W całej grupie badanej największe średnie wartości progowe przewodnictwa powietrznego obserwowano dla $6 \mathrm{kHz}$. Próg słuchu powyżej $25 \mathrm{~dB}$ HL dla przynajmniej jednej częstotliwości w zakresie $4-8 \mathrm{kHz}$ stwierdzono u 12 badanych w uchu prawym i u 15 - w uchu lewym. Stwierdzono, że w grupie słuchającej cicho muzyki średnie wartości progowe przewodnictwa powietrznego są istotnie statystycznie niższe w AT dla niektórych częstotliwości, zwłaszcza dla $6 \mathrm{kHz}$, niż w pozostałych grupach - słuchających muzyki o średnim natężeniu dźwięku i słuchających głośno, ale różnic takich nie wykazano w EHFA. Nie obserwowano również różnic istotnych dla średnich wartości progowych przewodnictwa powietrznego między grupami w zależności od częstości słuchania w osobistych odtwarzaczach muzyki.

Wnioski: W grupie studentów medycyny stwierdzono różnice istotne $\mathrm{w}$ audiometrii konwencjonalnej w zależności od głośności słuchania muzyki, ale nie od częstości słuchania w osobistych odtwarzaczach muzyki. Nie wykazano różnic w rozszerzonym zakresie wysokich częstotliwości w zależności od samooceny narażenia na potencjalny hałas związany ze słuchaniem muzyki.

Praca wykonana w ramach działalności statutowej, nr grantu 503/2-036-01/503-01. 


\section{Ocena wpływu stosowania doustnych leków antykoncepcyjnych na stan czynności ślimaka u młodych kobiet $w$ wieku między 20 a 30 rokiem życia przy użyciu otoemisji akustycznej - doniesienie wstępne}

\author{
Katarzyna Przytuła-Kandzia ${ }^{1}$, \\ Jarosław Markowski', \\ Aleksandra Ślaska-Kaspera ${ }^{1}$, \\ Agnieszka Widziszowska ${ }^{2}$ \\ ${ }^{1}$ Katedra i Klinika Laryngologii, SPSKM im. A. Mielęckiego \\ ŚUM, Katowice \\ 2 Ślaskie Centrum Stuchu i Mowy, Katowice
}

Słowa kluczowe: otoemisje akustyczne • TPOAEs • DPOAEs • narząd Cortiego • komórki słuchowe zewnętrzne • antykoncepcja doustna

\begin{abstract}
Wprowadzenie: Antykoncepcja hormonalna polega na stosowaniu pojedynczych syntetycznych hormonów płciowych lub ich kombinacji w celu zapobiegania ciąży. Na mechanizm działania doustnych środków antykoncepcyjnych (OC) składa się działanie estrogenu i gestagenu. Znany jest mechanizm zwiększonego występowania incydentów zakrzepowych w czasie stosowania OC, jednak nie do końca wiadomo, jak wpływa to na funkcję ślimaka. W literaturze światowej obecnych jest zaledwie kilka pozycji na ten temat. W związku z tym, iż badanie emisji otoakustycznych jest wysoce czułe i wykrywa zmiany subkliniczne, które nie dają jeszcze odchyleń w rutynowych badaniach audiologicznych, a także pozwala na obiektywną ocenę komórek słuchowych zewnętrznych (najbardziej narażonych na działanie czynników ototoksycznych) wykorzystano je do analizy wpływu stosowania doustnych leków antykoncepcyjnych na stan narządu słuchu.
\end{abstract}

Material i metody: Autorzy przedstawiają wstępne wyniki badań otoemisji akustycznych przeprowadzonych u 60 młodych kobiet. Grupa badana liczyła 30 otologicznie zdrowych kobiet zażywających doustne leki antykoncepcyjne min.1 rok, u których wyniki audiometrii tonalnej i impedancyjnej były prawidłowe. Grupa kontrolna to 30 młodych otologicznie zdrowych kobiet, które nigdy nie stosowały żadnej antykoncepcji.

Wyniki: Założeniem badania było wykazanie, że stosowanie doustnych leków antykoncepcyjnych wywołuje subkliniczne zmiany w narządzie słuchu, co odzwierciedla się $\mathrm{w}$ wynikach emisji otoakustycznych (TPOAEs i DPOAEs).
Ocena przydatności obiektywnych metod badania słuchu u dzieci i młodzieży z zespołem Downa - badania wstępne

\author{
Katarzyna Sienkiewicz, Adam Piłka, \\ Krzysztof Kochanek
}

Światowe Centrum Stuchu, Instytut Fizjologii i Patologii Stuchu, Warszawa/Kajetany

Słowa kluczowe: metody obiektywne badań słuchu - ABR, OAE, tympanometria • zespół Downa

Wprowadzenie: Częstość występowania zespołu Downa (ZD) wśród żywo urodzonych noworodków wynosi 1/600-700. Jest to najczęstsza aberracja ludzkich chromosomów autosomalnych. Jedną z przyczyn opóźnień $\mathrm{w}$ rozwoju intelektualnym i językowym u dzieci z zespołem Downa są zaburzenia słuchu. Szacuje się, że częstość występowania ubytków słuchu u dzieci z ZD wynosi od $38 \%$ do $82 \%$. Wielu badaczy zgadza się, że najczęściej występującym rodzajem niedosłuchu - jest niedosłuch przewodzeniowy, jednak inne źródła wskazuję także na niedosłuch mieszany lub czuciowo-nerwowy. Celem pracy była ocena możliwości wykonania i przydatności badań obiektywnych w diagnostyce narządu słuchu u dzieci i młodzieży z zespołem Downa.

Materiał i metody: W badaniach wsteppnych udział wzięło 12 osób z zespołem Downa w wieku od 8 miesięcy do 26 lat, 8 chłopców i 4 dziewczynki. Wykonano obiektywne metody badania słuchu - tympanometrię, otoemisję akustyczną oraz słuchowe potencjały wywołane pnia mózgu ABR. W badaniu tympanometrycznym stosowano częstotliwości tonu 220 i $1000 \mathrm{~Hz}$. W badaniach otoemisji stosowano w pierwszej kolejności pomiar TEOAE, a gdy nie stwierdzono obecności odpowiedzi, wykonywano pomiar emisji dla krótkich tonów o częstotliwościach 500 i 1000 $\mathrm{Hz}$ oraz DPOAE. Badanie słuchowych potencjałów wywołanych pnia mózgu - ABR wykonywano za pomocą urządzenia IntegrityV500 z wykorzystaniem trzasku. Badanie wykonywano procedurą szeregu natężeniowego, rozpoczynając od natężenia $70 \mathrm{~dB}$ nHL. Jeżeli było to możliwe, wyznaczano również wartości interwałów czasowych w odpowiedziach ABR.

Wyniki: Analiza wyników obiektywnych badań słuchu wykazała różnego rodzaju zaburzenia słuchu w badanej grupie pacjentów. Zaburzenie przewodzeniowe słuchu stwierdzono w jednym przypadku. W pozostałych przypadkach wyniki audiometrii impedancyjnej i odpowiedzi ABR były w normie.

Wnioski: Wyniki badań pilotażowych u dzieci i dorosłych z zespołem Downa potwierdziły możliwość zastosowania metod obiektywnych w ocenie słuchu tej grupy dzieci. 


\section{Głuchota w przebiegu guza kąta mostowo- -móżdżkowego u 5-letniego chłopca - opis przypadku}

\section{Renata Pepaś, Małgorzata Śmiechura, Małgorzata Strużycka, Wiesław Konopka}

Klinika Otolaryngologii ICZMP w Łodzi

Słowa kluczowe: guz kąta mostowo-móżdżkwego • głuchota $\bullet$ dzieci

Guzy kąta mostowo-móżdżkowego stanowią około 6-10\% zmian rozrostowych w obrębie ośrodkowego układu nerwowego. Najczęściej są to nerwiaki nerwu słuchowego (ok. 80-90\%), wrodzone perlaki (ok. 6\%) oraz oponiaki (ok. 6\%). U dorosłych nerwiaki w większości dotyczą kobiet, w średnim wieku 50-60 lat. Zwykle (w 95\% przypadków) są to guzy nabyte, jednostronne. Guzy kąta w populacji dziecięcej są stosunkowo rzadkie, a ich występowanie jest najczęściej związane $\mathrm{z}$ uwarunkowaną genetycznie neurofibromatozą typu 2, która dotyka 1 na 40000-50000 ludzi, a u ponad $95 \%$ chorych diagnozuje się nerwiaki nerwu VIII. Najbardziej charakterystycznym objawem jest obecność obustronnych nerwiaków nerwu przedsionkowo-ślimakowego. Przedstawiono przypadek 5-letniego chłopca, diagnozowanego w Klinice Otolaryngologii ICZMP, z powodu postępującego niedosłuchu w wywiadzie. W badaniu pediatrycznym i neurologicznym nie stwierdzono istotnych odchyleń od stanu prawidłowego. U pacjenta wykonano badanie otolaryngologiczne $\mathrm{z}$ nasofiberoskopią oraz diagnostykę audiologiczną (audiometrię tonalną, słowną i impedancyją), stwierdzając głuchotę ucha lewego, zarówno w badaniach subiektywnych jak i obiektywnych. W badaniu potencjałów słuchowych wywołanych lewostronnie nie stwierdzono odpowiedzi na bodziec $90 \mathrm{~dB}$. Wykonane badanie głowy z zastosowaniem rezonansu magnetycznego wykazało obecność litego guza o średnicy $20 \mathrm{~mm}$ w lewym kącie mostowo-móżdżkowym, prawdopodobnie o typie nerwiaka n. VIII. Pacjent został skierowany na leczenie neurochirurgiczne.

Wniosek: Guz okolicy kąta mostowo-móżdżkowego u 5 letniego chłopca stanowi wyjątkową rzadkość i mimo braku objawów neurofibromatozy typu 2, zarówno w badaniu podmiotowym jak i badaniach dodatkowych, wymaga przeprowadzenia dokładnej diagnostyki genetycznej.
Czuciowo-odbiorcze uszkodzenie słuchu oraz powikłania okulistyczne $w$ przebiegu wrodzonego zakażenia wirusem cytomegalii (CMV) u dzieci

Małgorzata Śmiechura ${ }^{1}$, Małgorzata Strużycka ${ }^{1}$, Lukasz Konopka ${ }^{2}$, Wiesław Konopka ${ }^{1,3}$

\author{
${ }^{1}$ Klinika Otolaryngologii ICZMP $w$ Łodzi \\ ${ }^{2}$ Klinika Okulistyki i Rehabilitacji Wzrokowej II Katedry Oczu \\ Uniwersytetu Medycznego $w$ Łodzi \\ ${ }^{3}$ Uniwersytet Medyczny w Łodzi
}

Słowa kluczowe: CMV • uszkodzenie słuchu • zaburzenia widzenia $\bullet$ dzieci

Objawowa cytomegalia jest związana z 90\% ryzykiem wystąpienia następstw neurologicznych, w tym z ryzykiem uszkodzenia słuchu czy zaburzeń okulistycznych. Objawy okulistyczne wrodzonego zakażenia CMV mogą dotyczyć od 5\% do 30\% dzieci. Najczęściej są to zaburzenia tylnego odcinka gałki ocznej jak retinochorioiditis, blizny w plamce oraz siatkówki obwodowej, zanik nerwu wzrokowego jak również zapalenie błony naczyniowej. Patologia odcinka przedniego oka występuje pod postacią zaćmy wrodzonej oraz blizn rogówki. Uważa się, że z wrodzonym zakażeniem CMV mogą współwystępować zez, małoocze czy brak gałki ocznej. Niedosłuch pojawia się u około 30-60\% dzieci z objawowa cytomegalia wrodzoną. W przypadkach wrodzonej postaci zakażenia CMV ponad połowa badanych w naszym materiale miała obustronny głęboki niedosłuch odbiorczy ( $w$ audiometrii tonalnej progowej krzywe przewodnictwa powietrznego i kostnego w zakresie niskich i średnich częstotliwości na poziomie $70 \mathrm{~dB}$, natomiast dla częstotliwości powyżej $2000 \mathrm{~Hz}$ na poziomie $90 \mathrm{~dB}$ ). Obecność fali $\mathrm{V}$ w badaniu ABR zarejestrowano obustronnie na poziomie $90 \mathrm{~dB}$. W grupie dzieci z cytomegalia nabyta $\mathrm{w}$ naszym materiale $\mathrm{u}$ wszystkich stwierdzono próg słuchu w audiometrii tonalnej progowej w granicach normy (10-20 dB), prawidłowe wyniki audiometrii impedancyjnej, obecność otoemisji akustycznej wywołanej (TEOAE), próg słuchu w badaniu ABR na poziomie 15-20 dB. Mimo prawidłowego słuchu u części badanych stwierdzony był opóźniony rozwój psychoruchowy.

Wnioski: 1. U dzieci z wywiadem zakażenia CMV nawet po prawidłowym wyniku badań przesiewowych słuchu konieczna jest długoterminowa okresowa kontrola słuchu. 2. Uszkodzenie słuchu może wystąpić także w bezobjawowym zakażeniu (wrodzonym i nabytym) CMV, stąd konieczne są kontrolne badania słuchu do zakończenia okresu rozwoju mowy, przeprowadzane co 6 miesięcy. 3. Pogorszenie widzenia najczęściej w przebiegu chorioretinitis jest częstym następstwem wrodzonej cytomegalii, zwłaszcza w postaci objawowej. 


\section{Wartość praktyczna analizy akustycznej wybranych instrumentów muzycznych stosowanych $w$ diagnostyce audiologicznej}

\section{Barbara Bilińska, Katarzyna Paluszak, Anna Hashimoto, Piotr Swidziński, Bogna Małaczyńska}

Katedra i Klinika Foniatrii i Audiologii UM w Poznaniu

Słowa kluczowe: VRA • instrumenty muzyczne • diagnostyka małych dzieci

Szerokie spektrum badań audiologicznych stosowanych w diagnostyce osób dorosłych pozwala na zachowanie zasady „cross check principle”. Niestety każda metoda badawcza jest obarczona ograniczeniami technicznymi. Wachlarz metod diagnostycznych niemowląt i małych dzieci jest dużo mniejszy niż u dorosłych. Do określenia progu słuchowego u dzieci wykorzystuje się badanie ABR, OAE, audiometrie impedancyjną, rzadziej badania subiektywne. Do określenia zysku z aparatu wykorzystuje się badanie audiometrią zabawową VRA. Do rozszerzenia możliwości tej metody wykorzystuje się również instrumenty muzyczne. Aby określić orientacyjne progi słuchowe pacjenta, niezbędna jest wiedza o zakresie częstotliwości i natężeniu danego instrumentu. Celem pracy było opracowanie akustyczne widm oraz ich dynamiki poziomu natężenia. W badaniach wykorzystano 17 instrumentów muzycznych $\mathrm{z}$ „Torby małego muzyka”: tamburyn, śr. $20 \mathrm{~cm}$ - maxi quiro z pałeczką, dł. $40 \mathrm{~cm}$ - podwójna tarka quiro z pałeczką, dł. $27 \mathrm{~cm}$ - trójkąty z pałeczkami, 5 szt., wym. 20,5 $\mathrm{cm}, 17,5 \mathrm{~cm}, 15,5 \mathrm{~cm}, 13 \mathrm{~cm}, 10,5 \mathrm{~cm}$ - kastaniety drewniane, 2 szt., śr. $5,5 \mathrm{~cm}$ - kastaniety z rączką, dł. $21 \mathrm{~cm}-$ marakasy drewniane, dł. $23 \mathrm{~cm}$ - drewniany tonblok, $\mathrm{d}$. $20 \mathrm{~cm}$, śr. $4,5 \mathrm{~cm}$ - tamburyn $\mathrm{z}$ membraną, śr. $20 \mathrm{~cm}$ podwójny tonblok z pałeczką, dł. $20 \mathrm{~cm}$, śr. $4,5 \mathrm{~cm}-$ podwójny tonblok mały z pałeczką, dł. $20 \mathrm{~cm}$, śr. $3,5 \mathrm{~cm}-$ klawesy, dł. $20 \mathrm{~cm}$, śr. 2,2 cm - marakas wałek, dł. 20,5 $\mathrm{cm}$, śr. $5 \mathrm{~cm}$. W taki sposób badanie orientacyjne słuchu $\mathrm{u}$ dzieci jest możliwe za pomocą wykalibrowanych instrumentów muzycznych.

\section{Analiza akustyczna głosu przetokowego u pacjentów $\mathrm{z}$ protezą głosową typu Provox 2}

\section{Jarosław Markowski, Małgorzata Witkowska, Olga Leśniewska, Agnieszka Piotrowska-Seweryn}

Katedra i Klinika Laryngologii, Ślaski Uniwersyte Medyczny w Katowicach

Słowa kluczowe: proteza głosowa • głos przetokowy

Wstęp: Utrata głosu i mowy po operacji całkowitego usunięcia krtani uznawana jest za dominujący czynnik poczucia niepełnosprawności i kalectwa przez pacjentów laryngektomowanych. Stąd konieczne jest wypracowanie najlepszego sposobu rehabilitacji mowy. Jednym z nich jest chirurgiczna metoda wszczepienia protezy przełykowo-tchawiczej typu Provox 2. Celem pracy była ocena parametrów akustycznych głosu przetokowego u pacjentów laryngektomowanych z wszczepioną protezą głosową typu Provox 2.

Materiał i metody: Badaniem objęto grupę chorych z protezą głosową typu Provox 2 wszczepioną wtórnie. Do grupy kontrolnej włączono pacjentów laryngektomowanych w latach 2007-2012, którzy wykształcili mowę przełykową w stopniu I wg skali Pruszewicza.

Przeprowadzono subiektywne badanie akustyczne $\mathrm{z}$ oceną płynności mowy, liczby sylab wypowiadanych na jednym zaczerpnięciu, charakteru mowy, sposobu tworzenia głosu oraz pełną analizę akustyczną za pomocą oprogramowania IRIS, oceniając następujące parametry: całkowity czas fonacji (MPT), średnią częstotliwość podstawową, (F0), jitter local, shimmer local, HNR (dla samogłoski „a”), a także natężenie głosu o stopień bezgłosu (DUV). Dodatkowo pacjenci grupy badanej dokonali oceny skuteczności rehabilitacji głosu według zmodyfikowanej (do warunków polskich) skali Harrison-Robilliard-Schulz (HRS). Chorzy obu grup ocenili skuteczność rehabilitacji głosu za pomocą ankiety VHI. Uzyskane wyniki skorelowano z niektórymi danymi klinicznymi, jak wiek, stopień zaawansowania klinicznego według klasyfikacji TNM, zastosowanie terapii adiuwantowej (radioterapia, chemioterapia), obecność powikłań.

\section{Emisje otoakustyczne przed i po słuchaniu muzyki na przenośnym odtwarzaczu CD}

Bartosz Trzaskowski, Wiesław Wiktor Jędrzejczak, Edyta Piłka, Magdalena Cieślicka, Henryk Skarżyński

Światowe Centrum Słuchu, Instytut Fizjologii i Patologii Słuchu, Warszawa/Kajetany

Słowa kluczowe: głośna muzyka • emisje otoakustyczne • TEOAE • DPOAE • TTS • przenośny odtwarzacz płyt CD

Wprowadzenie: Wpływ przenośnych odtwarzaczy muzyki na układ słuchowy wciąż nie został jeszcze do końca zbadany. Emisje otoakustyczne (OAE) okazały się dobrym wskaźnikiem funkcji ślimaka. Wyniki ostatnich badań sugerują, że mogą być czulsze niż audiometria tonalna i dzięki nim można wykryć potencjalne upośledzenie funkcji ślimaka wcześniej niż za pomocą standardowych technik audiometrycznych.

Materiał i metody: Przebadana w ramach niniejszej pracy grupa dwudziestu dorosłych osób z prawidłowym słuchem słuchała muzyki z przenośnego odtwarzacza płyt CD. Każda osoba miała wykonane badanie emisji otoakustycznych wywołanych trzaskiem (TEOAE), emisji produktów zniekształceń nieliniowych (DPOAE) oraz audiometrii tonalnej (PTA) na trzech etapach: przed słuchaniem muzyki, po słuchaniu muzyki trwającym 30 minut (poziom: 86,6 dBA) i po upływie ok. 24 godzin. 
Wyniki: Analiza uzyskanych danych wykazała, że w badanej grupie nie wystąpiły żadne istotne statystycznie zmiany w parametrach zarówno OAE, jak i PTA związane ze słuchaniem muzyki.

Wnioski: Wynik ten pozwala sformułować wniosek, że ekspozycja na muzykę o parametrach jak w niniejszej pracy, nie wprowadza zaburzeń funkcji ślimaka, które mogłyby być wykryte na podstawie wyników badań emisji otoakustycznych (TEOAE i DPOAE) oraz audiometrii tonalnej.

\section{Zaburzenia językowe i komunikacyjne w schizofrenii - doniesienia wstępne}

\author{
Joanna Kasperuk ${ }^{1}$, Anna Kraszewska ${ }^{1}$, \\ Napoleon Waszkiewicz ${ }^{2}$, Anna Rogowska ${ }^{2}$, \\ Dawid Falkowski ${ }^{1}$, Jolanta Biszewska ${ }^{1}$, \\ Agata Szulc ${ }^{2}$

\section{${ }^{1}$ Zakład Fonoaudiologii Klinicznej i Logopedii UM $w$ Bialymstoku \\ ${ }^{2}$ Klinika Psychiatrii Uniwersytetu Medycznego w Bialymstoku}

Słowa kluczowe: schizofrenia • schizofazja • zaburzenia językowe • zaburzenia komunikacyjne

Wstęp: Schizofrenia nie tworzy jednostki nozologicznej, mianem tym określa się grupę zaburzeń psychicznych, których wspólną cechą jest rozpad osobowości. Wyróżniamy cztery główne postaci schizofrenii - paranoidalną, prostą, hebefreniczną i katatoniczną - różniące się między sobą obrazem klinicznym. Jedną z cech charakterystycznych przewlekłej schizofrenii jest występowanie w obrazie klinicznym objawów patologii języka m.in. schizofazji. Celem pracy była analiza zaburzeń języka i komunikacji w schizofrenii przewlekłej.

Materiał i metody: Badaniom poddano grupę 20 pacjentów ze zdiagnozowaną schizofrenią przewlekłą, leczonych w Klinice Psychiatrii Uniwersytetu w Białymstoku. Zaburzenia języka i komunikacji badano na podstawie próbek mowy spontanicznej analizowanych następującymi narzędziami badawczymi: Krótka Skala Oceny Schizofazji (KSOS) oceniająca spójność gramatyczną, semantyczną i pragmatyczną wypowiedzi oraz Skala Oceny Zaburzeń Myślenia, Języka i Komunikacji (TLC).

Wyniki: Zaburzenia języka i komunikacji stanowią niezwykle istotny problem $\mathrm{w}$ terapii pacjenta ze schizofrenią. Schizofazja osiąga różny stopień nasilenia - koreluje pozytywnie $\mathrm{z}$ nasileniem psychopatologii oraz z przewlekłością psychozy schizofrenicznej. Na fenomen schizofazji składają się różne zjawiska językowe - najczęściej występuje dysfunkcja spójności tekstu, w zaawansowanych przypadkach dochodzi również do dysfunkcji leksykalnej. Należy podkreślić, że możemy zaobserwować liczne nieschizofatyczne wypowiedzi osób ze zdiagnozowaną schizofrenią, dlatego też utożsamianie schizofrenii ze schizofazją jest dużym uproszczeniem. Zakłócenia komunikacji w schizofrenii spowodowane są nie tylko zaburzeniami językowymi, lecz wynikają także z zaburzeń myślenia - u ich genezy leżą zaburzenia funkcji poznawczych.
Wnioski: Ocena zaburzeń językowych pozwala na zrozumienie mechanizmów zaburzeń komunikacji pacjentów chorych na schizofrenię, tym samym przyczyniając się do opracowania efektywniejszych metod rehabilitacji, które mogą przywrócić pacjentom zdolność do funkcjonowania społecznego.

\section{Zawroty głowy i zaburzenia równowagi jako początkowy objaw zatorowości płucnej}

\section{Monika Woźniak, Ireneusz Kantor, Marzena Kubiczek-Jagielska}

Klinika Laryngologii CMKP w Warszawie

Słowa kluczowe: zawroty głowy • zatorowość płucna • czynniki ryzyka

Zatorowość płucna jest stanem kardiologicznym, stanowiącym bezpośrednie zagrożenie życia, często trudnym diagnostycznie, o nieprzewidywalnym przebiegu. Charakteryzuje się szerokim panelem objawów od słabo zaznaczonej męczliwości, kaszlu, dyskretnych dolegliwości bólowych w klatce piersiowej w ubogo symptomatycznej postaci niemasywnej choroby, po nasiloną duszność, objawy wstrząsu aż do nagłego zatrzymania krążenia w postaci masywnej. W pracy przedstawiono dwa przypadki pacjentek przyjętych do Kliniki Laryngologii w trybie nagłym $\mathrm{z}$ powodu zawrotów głowy z towarzyszącym oczopląsem jako jedynym objawem zaburzeń ogólnoustrojowych. W trakcie hospitalizacji stwierdzono znacznie przekraczający przyjętą normę poziom d-dimerów, co ukierunkowało dalszy tok postępowania diagnostycznego i terapeutycznego. Autorzy pracy zwrócili też uwagę na bardzo zróżnicowaną etiologię choroby i najczęstsze czynniki ryzyka. Opisali kolejne etapy procesu diagnostycznego od oceny laryngologicznej, otoneurologicznej i audiologicznej po badania internistyczne i obrazowe. Przedstawili również zalecane metody postępowania leczniczego i podkreślili konieczność prowadzenia długotrwałej i skrupulatnej katamnezy w celu zapobiegania nawrotom choroby.

\section{Ocena audiometrycznego testu manualnego i automatycznego $w$ badaniach osób w wieku senioralnym}

\section{Magdalena Kręglicka ${ }^{1}$, Lech Śliwa ${ }^{2}$, Krzysztof Kochanek ${ }^{1,2}$, Adam Piłka ${ }^{2}$}

\footnotetext{
${ }^{1}$ Zakład Logopedii i Językoznawstwa Stosowanego, UMCS Lublin

${ }^{2}$ Światowe Centrum Stuchu, Instytut Fizjologii i Patologii Stuchu, Warszawa/Kajetany
}

Słowa kluczowe: badania przesiewowe słuchu

Wprowadzenie: Zaburzenia słuchu i związane z nimi zaburzenia procesów komunikacyjnych są częstym problemem w populacji osób w wieku senioralnym. Ich skutkiem jest pogorszenie jakości życia, a w skrajnych przypadkach wykluczenie społeczne. Skuteczne przeciwdziałanie 
skutkom zaburzeń słuchu i komunikacji wymaga wczesnego wykrywania problemów i wczesnej interwencji. Celem pracy było zbadanie możliwości wykorzystania znanych metod badań przesiewowych słuchu w populacji senioralnej. Oceniano skuteczność metod i łatwość korzystania $\mathrm{z}$ nich przez osoby starsze.

Materiał i metody: W badaniach uczestniczyło 15 osób (8 kobiet, 7 mężczyzn) w wieku 60-92 lat. Jedna $z$ badanych osób posiada już aparat słuchowy. Do badań wykorzystano urządzenie Audiometr S, umożliwiający wykonanie testów audiometrycznych manualnych i automatycznych. Wykonano ponadto badanie kwestionariuszem HHIE-S przetłumaczonym na język polski oraz ankietę, w których oceniano trudność wykonania poszczególnych testów.

Wyniki: Wyniki badań wskazują, że automatyczne testy audiometryczne mogą być $\mathrm{z}$ powodzeniem stosowane u osób w wieku senioralnym.

Wnioski: Wskazane jest także wykonanie testów oceniających centralne procesy słuchowe, takich jak GDT itp.

\section{Ocena skuteczności rehabilitacji słuchowej u dzieci po wszczepieniu implantu ślimakowego $\mathrm{z}$ wykorzystaniem kwestionariusza LittlEARS}

\section{Anita Obrycka, Artur Lorens, Anna Piotrowska, Henryk Skarżyński}

Światowe Centrum Stuchu, Instytut Fizjologii i Patologii Słuchu, Warszawa/Kajetany

Słowa kluczowe: niedosłuch, implanty ślimakowe, rehabilitacja słuchowa, kwestionariusz LitllEars

Cel: Ocena skuteczności rehabilitacji słuchowej u dzieci, którym wszczepiono implant ślimakowy przed ukończeniem drugiego roku życia.

Materiał i metody: 122 dzieci z obustronnym głębokim niedosłuchem zmysłowo nerwowym, kolejno implantowanych w Instytucie Fizjologii i Patologii Słuchu po 1.10 .2007 r. Średni wiek w chwili aktywacji implantu wyniósł 14,30 miesiąca (min. 7,87 miesiąca, max. 23,47 miesiąca, $\mathrm{SD}=3,97)$. Przed wszczepieniem implantu ślimakowego u wszystkich dzieci podejmowana była próba obustronnego protezowania $\mathrm{z}$ wykorzystaniem aparatów słuchowych.

Aby dokonać oceny skuteczności rehabilitacji, z badanej grupy wyodrębniono grupę dzieci implantowanych powyżej 18 miesiąca życia, korzystających przed wszczepieniem implantu $\mathrm{z}$ aparatów słuchowych oraz grupę dzieci implantowanych przed ukończeniem 12 miesiąca życia i korzystających z implantu minimum 6 miesięcy.

Do oceny skuteczności rehabilitacji słuchowej wykorzystano kwestionariusz LittlEARS. Wynik badania kwestionariuszem można porównać do normy wiekowej lub wykorzystać do określenia wieku słuchowego dziecka z niedosłuchem. Jako wyznacznik skuteczności rehabilitacji słuchowej przyjęto opóźnienie rozwoju słuchowego $\mathrm{u}$ dzieci korzystających $\mathrm{z}$ implantu w stosunku do dzieci ze słuchem prawidłowym. Opóźnienie to zostało wyliczone jako różnica wieku metrykalnego i słuchowego.

Wyniki: Nieadekwatny do wieku poziom rozwoju słuchowego w chwili aktywacji implantu zidentyfikowano u 108 dzieci (86\%) z badanej grupy. Wśród dzieci implantowanych przed ukończeniem pierwszego roku życia, po około 10 miesiącach korzystania z implantu $43,8 \%$ osiągnęło prawidłowy rozwój słuchowy, 40,6\% charakteryzowało się nie większym niż czteromiesięcznym opóźnieniem tego rozwoju, natomiast opóźnienie u pozostałych $15,6 \%$ dzieci nie przekroczyło 8 miesięcy. W grupie dzieci implantowanych powyżej 18 miesięcy, w chwili aktywacji implantu, po około 10 miesiącach korzystania $\mathrm{z}$ aparatów słuchowych normy dla rozwoju słuchowego nie osiągnęło żadne z dzieci, u 5,3\% dzieci opóźnienie rozwoju słuchowego nie przekraczało 4 miesięcy, u 26,3\% dzieci zawierało się w przedziale od 8 do12 miesięcy, u $21,1 \%$ dzieci w przedziale od 12 do 18 miesięcy, natomiast w 47,4\% przypadków wynosiło powyżej 18 miesięcy. Długookresowa obserwacja wyników uzyskanych przez dzieci implantowane poniżej pierwszego roku życia wskazuje, że po ok. 12 miesiącach korzystania $\mathrm{z}$ implantu dzieci te osiągają poziom rozwoju słuchowego nieodbiegający od normy.

Wnioski: Kwestionariusz LittlEARS jest narzędziem pozwalającym na ocenę skuteczności rehabilitacji słuchowej. $\mathrm{W}$ grupie dzieci z obustronnym głębokim niedosłuchem typu odbiorczego zastosowanie rehabilitacji medycznej $\mathrm{z}$ wykorzystaniem implantu ślimakowego w wieku poniżej 12 miesięcy pozwala na osiągnięcie poziomu rozwoju słuchowego nieodbiegającego od normy przed ukończeniem przez te dzieci drugiego roku życia.

Projekt został sfinansowany ze środków Narodowego Centrum Nauki przyznanych na podstawie decyzji numer DEC-2012/05/N/ST7/02006.

\section{Ocena percepcyjno-akustyczna głosu i mowy u chorych na idiopatyczną chorobę Parkinsona}

Anna Orkisz-Popczyk ${ }^{1}$, Jarosław Markowski ${ }^{1}$, Agnieszka Gorzkowska ${ }^{2}$, Wirginia Likus ${ }^{3}$

\footnotetext{
${ }^{1}$ Katedra i Klinika Laryngologii SUM, Katowice

${ }^{2}$ Katedra i Klinika Neurologii SUM, Katowice

${ }^{3}$ Katedra i Zakład Anatomii Prawidłowej SUM, Katowice
}

Choroba Parkinsona jest postępującym schorzeniem ośrodkowego układu nerwowego. Częstość występowania w populacji ogólnej szacuje się na około $0,15 \%$. W Polsce choruje około 70 tysięcy osób. Średni wiek zachorowania wynosi 58 lat. U blisko $90 \%$ osób cierpiących na chorobę Parkinsona należy spodziewać się zaburzeń mowy, głosu oraz połykania i węchu. Powyższe trudności sprzyjają izolacji społecznej. W dobie współczesnego rozwoju technik komputerowych, miniaturyzacji oraz dążenia do nieinwazyjności badań coraz częściej wykonywane są obiektywne metody 
akustyczne badania głosu. Pozwalają one sparametryzować oraz przedstawić $\mathrm{w}$ formie zapisu graficznego sygnały akustyczne mowy.

Obraz kliniczny zaburzeń głosu i mowy u chorych z chorobą Parkinsona jest wielostronny i dotyczy artykulacji na skutek dyskoordynacji mięśni aparatu artykulacyjnego, fonacji - na skutek nieprawidłowej czynności i różnego stopnia napięcia mięśni wewnętrznych krtani, zwłaszcza przywodzących fałdy głosowe; występują zaburzenia barwy głosu i jego natężenia, oddychania - na skutek obniżonej pojemności życiowej płuc.

Celem pracy była charakterystyka częstotliwości podstawowej oraz ocena analizy formantowej u osób z rozpoznaną idiopatyczną chorobą Parkinsona, analiza percepcyjno-akustyczna w dysartrofonii chorych $\mathrm{z}$ idiopatyczną chorobą Parkinsona oraz ocena wpływu niepełnosprawności głosu i mowy na jakość życia osób z idiopatyczną chorobą Parkinsona.

Zbadano 39 osób z idiopatyczną chorobą Parkinsona, w tym 17 kobiet i 22 mężczyzn w wieku 45 do 81 lat, oraz 39 osób zdrowych, w tym 17 kobiet i 22 mężczyzn w wieku 49 do 81 lat.

Wnioski: Stwierdzono istotną statystycznie zależność pomiędzy podwyższeniem niektórych wartości parametrów fonetyczno-akustycznych w idiopatycznej chorobie Parkinsona w porównaniu $\mathrm{z}$ grupą kontrolną osób zdrowych z uwzględnieniem płci w obu grupach. Następstwem idiopatycznej choroby Parkinsona jest nieprawidłowa wibracja fałdów głosowych oraz dysfonia hyperfunkcjonalna, które potwierdzono oceną akustyczno-percepcyjną głosu. Wykazano istotny statystycznie wpływ niepełnosprawności głosu na sferę funkcjonalną i emocjonalną chorych $\mathrm{z}$ chorobą Parkinsona.

\section{Zastosowanie elektrycznego dopełnienia lub stymulacji elektryczno-akustycznej u dzieci po leczeniu częściowej głuchoty}

\section{Małgorzata Zgoda, Artur Lorens, Agata Lutek, Joanna Putkiewicz-Aleksandrowicz, Henryk Skarżyński}

Światowe Centrum Stuchu, Instytut Fizjologii i Patologii Stuchu, Warszawa/Kajetany

Słowa kluczowe: częściowa głuchota, stymulacja elektryczno-akustyczna, próg rozumienia mowy

Wprowadzenie: Wyjątkowe możliwości rehabilitacji u dzieci z częściową głuchotą daje zastosowanie elektrycznego dopełnienia prawidłowego słyszenia niskich częstotliwości przez dodanie odbioru wysokich dźwięków przez implant. W przypadku gdy czułość słyszenia dla tonów niskich jest przed operacją lub po niej obniżona, potrzebne jest zastosowanie dodatkowego wzmocnienia akustycznego w zakresie niskich częstotliwości (stymulacja elektryczno-akustyczna). Próby protezowania za pomocą aparatów słuchowych dzieci z częściową głuchotą nie dają zadowalających efektów. Brak słyszenia dźwięków o wysokiej częstotliwości nie pozwala na wystarczającą kompensację ubytku słuchu na drodze akustycznego wzmocnienia realizowanego przez aparaty słuchowe. Ograniczenia w odbiorze dźwięków w okresie rozwojowym może znacząco rzutować na wyniki rehabilitacji słuchu i mowy w tej grupie pacjentów. Leczenie częściowej głuchoty z użyciem implantów ślimakowych poszerzyło grupę dzieci mogących uzyskać poprawę słyszenia. Celem pracy była cena dyskryminacji mowy po zastosowania stymulacji dopełniającej oraz elektryczno-akustycznej w grupie młodszych dzieci po leczeniu częściowej głuchoty.

Materiał i metody: Wybrana losowo grupa 21 dzieci po leczeniu częściowej głuchoty za pomocą implantów ślimakowych została zakwalifikowana do grupy badawczej. Wiek dzieci w badanej grupie zawierał się w przedziale od 5 do 14 lat. Do oceny dyskryminacji mowy przy zastosowaniu stymulacji dopełniającej oraz elektryczno-akustycznej wykorzystano Adaptacyjny Test Oceny Progu Rozumienia Mowy - Adaptive Auditory Speech Test (AAST) w ciszy i w szumie, przeprowadzony w czterech warunkach odsłuchowych - odbiór: tylko akustyczny, tylko elektryczny, z elektrycznym dopełnieniem lub elektryczno-akustyczny oraz w najlepszych warunkach odsłuchowych. Badanie przeprowadzono u pacjentów korzystających z implantu od minimum roku.

Wyniki: Dyskryminacja mowy w warunku odsłuchowym z elektrycznym dopełnieniem lub stymulacją elektryczno-akustyczną oraz w najlepszych warunkach przewyższa odbiór mowy w warunku stymulacji tylko akustycznej lub tylko elektrycznej w przypadku dzieci po leczeniu częściowej głuchoty.

Wnioski: Zastosowanie elektrycznego dopełnienia lub stymulacji elektryczno-akustycznej jest skuteczną metodą rozwoju dyskryminacji mowy u dzieci po leczeniu częściowej głuchoty za pomocą implantów ślimakowych.

\section{Ocena skuteczności i efektywności zastosowania systemu BAHA Attract - pierwsze wyniki}

\section{Anna Ratuszniak, Lukasz Olszewski, Ewelina Kołsut, Piotr Henryk Skarżyński, Maciej Mrówka, Henryk Skarżyński}

Światowe Centrum Stuchu, Instytut Fizjologii i Patologii Stuchu, Warszawa/Kajetany

Słowa kluczowe: aparat zakotwiczony w kości • BAHA Attract • kostne przewodnictwo dźwięków • przewodzeniowy ubytek słuchu

Wprowadzenie: System BAHA Attract to niepenetrujące skóry urządzenie wykorzystujące kostne przewodnictwo dźwięków. W systemie tego rodzaju, w przeciwieństwie do stosowanego od lat systemu BAHA Connect, nie dochodzi do bezpośredniego kontaktu części wszczepionej i zewnętrznej. Implant oraz magnes umieszczony jest całkowicie pod skórą, a procesor podłączony do zewnętrznego magnesu utrzymywany jest bezpośrednio nad częścią 
wszczepioną. Dzięki tego rodzaju rozwiązaniu możliwie jest ograniczenie liczby ewentualnych powikłań, związanych głównie z infekcjami obszaru skóry wokół zaczepu, stanami zapalnymi, skutkującymi w skrajnych przypadkach wydzieleniem się implantu. Cel: Ocena korzyści z zastosowania nowej technologii BAHA Attract w grupie pacjentów $\mathrm{z}$ niedosłuchem przewodzeniowym o różnej etiologii.

Materiał i metody: Materiał pracy stanowi grupa 8 pacjentów $\mathrm{z}$ jedno- lub obustronnym ubytkiem słuchu typu przewodzeniowego, 5 kobiet, 3 mężczyzn, średni wiek 31 lat, poddanych zabiegowi wszczepienia zaczepu do systemu BAHA Attract w Instytucie Fizjologii i Patologii Słuchu. Podłączenie zewnętrznego procesora następowało w odstępie ok. 4 tygodni od zabiegu. Oceny skuteczności zastosowanego rozwiązania dokonano za pomocą audiometrii wolnego pola oraz testów słownych (określenie progu SRT w ciszy i w szumie) w odstępie 1 i 3 miesięcy od podłączenia procesora. Efektywność oceniono w analogicznych odstępach czasu przy użyciu kwestionariusza APHAB oraz ankiety własnej skonstruowanej na potrzeby badania.

Wyniki i wnioski: Uzyskane wyniki potwierdzają skuteczność zastosowanego sposobu protezowania pacjentów $\mathrm{z}$ niedosłuchem przewodzeniowym. Zastosowanie systemu BAHA Attract daje możliwość poprawy jakości funkcjonowania słuchowego, swobodnej komunikacji, urządzenie jest również dobrze akceptowane przez pacjentów w życiu codziennym. 